\title{
Redescription of Tetramorium forte Forel, 1904 (Insecta: Hymenoptera: Formicidae), a western Mediterranean ant species
}

\author{
ROBERT GÜSTEN ${ }^{1}$, ANDREAS SCHULZ ${ }^{2} \&$ MATTHIAS SANETRA ${ }^{3}$ \\ ${ }^{1}$ Hessisches Landesmuseum Darmstadt, Naturgeschichtliche Abteilung, Friedensplatz 1, D-64287 Darmstadt, \\ Germany.E-mail: robertgusten@aol.com \\ ${ }^{2}$ Paracelsusstraße 14,D-51375 Leverkusen, Germany.E-mail: schulz_ant@web.de \\ ${ }^{3}$ Zoology and Evolutionary Biology, Universität Konstanz, Universitätsstraße 10, D-78457 Konstanz, Ger- \\ many.E-mail: matthias.sanetra@uni-konstanz.de
}

\section{Table of contents}

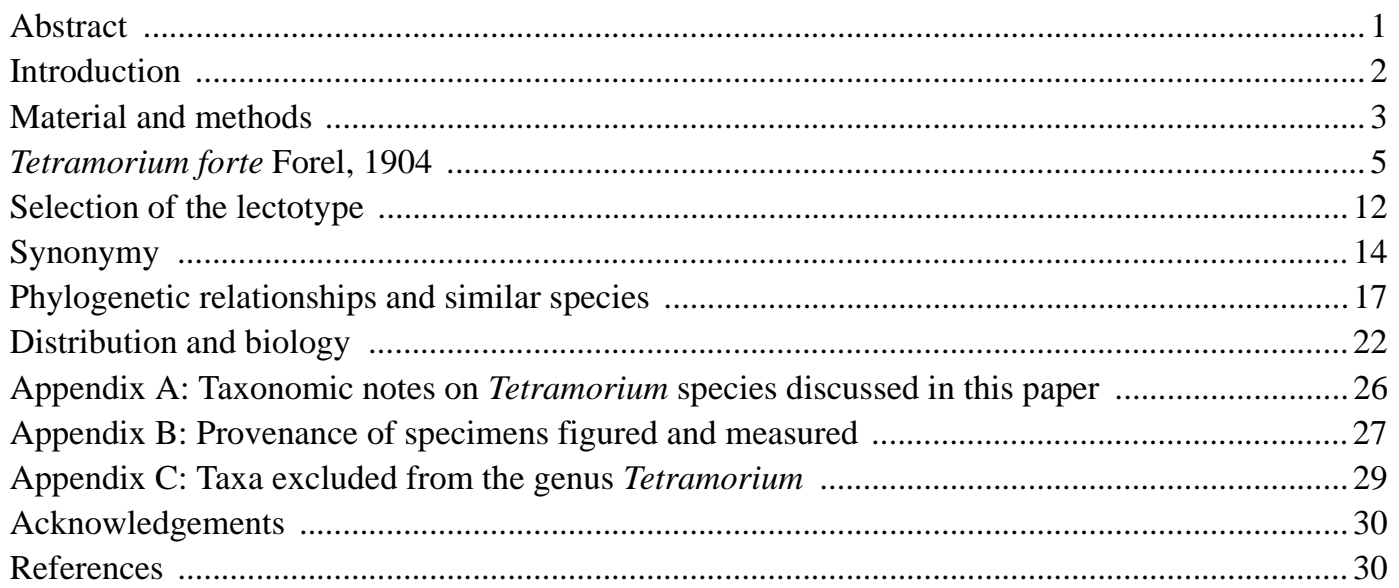

\begin{abstract}
The western Mediterranean ant species Tetramorium forte Forel, 1904 is redescribed and a lectotype is designated. Taxonomic controversy surrounding the application of the name and its synonymy is thereby resolved: T. ruginode Stitz, 1917 (with its junior synonym T. hispanicum Bondroit, 1918), T. maurum tingitanum Santschi, 1929 and T. maroccanum De Haro \& Collingwood, 1994 are relegated to synonymy with $T$. forte. Lectotypes are designated for $T$. hispanicum, T. maurum tingitanum, T. maroccanum and T. silvestrianum Emery, 1924. The latter taxon, previously regarded as a junior synonym of $T$. forte, is synonymized with Myrmica
\end{abstract}


specioides Bondroit, 1918. The distribution of T. forte is outlined, which encompasses southern France, the Iberian Peninsula and parts of the western Maghreb. Numerous new records are cited from throughout this range. Characters that distinguish $T$. forte from the similar species $T$. chefketi Forel, 1911, T. alternans Santschi, 1929 nov. stat. and T. moravicum Kratochvil, 1941, are presented. The latter species geographically overlaps with $T$. forte in southeastern France. Life history information available for T. forte is summarized.

Key words: Myrmicinae, Tetramoriini, taxonomy, lectotype designation, distribution, identification

\section{Introduction}

In the Palaearctic region, species level taxonomy in the ant genus Tetramorium Mayr, 1855 has remained a particularly challenging issue (López 1991; Seifert 1996; Radchenko et al. 1998; Sanetra et al. 1999; Sanetra \& Buschinger 2000; Steiner et al. 2005). This is mainly due to the high morphological variability in the worker caste, the lack of diagnostic characters useful for species distinction and the large number of infraspecific entities described by early myrmecologists. While the Tetramorium taxa of other zoogeographical regions have been thoroughly revised (Bolton 1976, 1977, 1979, 1980), progress in the Palaearctic has been confined to partial revisions of local faunae with varying success (e.g. López 1991; Radchenko 1992; Cagniant 1997; Sanetra et al. 1999). Even the very common and widespread species T. caespitum (Linnaeus, 1758) and T. impurum (Förster, 1850) have been reliably distinguished only recently (Cammaerts et al. 1985; Seifert 1996) but new data suggest that they in turn are an assembly of cryptic species (Steiner et al. 2002; Schlick-Steiner et al., 2006).

It is thus not surprising that in species-rich parts of the Palaearctic, such as the Mediterranean region and particularly southeastern Europe and the Middle East, most Tetramorium species are neither well defined morphologically nor satisfactorily delimited in their geographic ranges. Fewer species seem to occur in the southwestern parts of Europe (e.g. Iberian Peninsula) than on the Apennine Peninsula (Sanetra et al. 1999) and the Balkans (Sanetra \& Buschinger 2000; Steiner et al. 2005; Schlick-Steiner et al., in press). We here give detailed taxonomic and distributional information on a species well represented in the western Mediterranean region (southern France, Iberian Peninsula, northwestern Africa), which has not been characterized satisfactorily, and whose correct name has been controversial for a long time. The name we stabilize here for this taxon, Tetramorium forte Forel, 1904, has occasionally been applied to other taxonomic species, including eastern European ones (e.g. T. moravicum Kratochvil, 1941), while T. forte as defined here has often been referred to by its junior synonyms T. ruginode Stitz, 1917 or $T$. hispanicum Bondroit, 1918. The prevalent confusion has been at least partly caused by the type material containing several taxonomic species. Thus, to achieve nomenclatural stability for this ant species after 100 years, a lectotype of $T$. forte is designated. 
Types and other critical specimens from the following collections have been studied:

MHNG Muséum d’Histoire Naturelle de Genève, Switzerland

NHMB Naturhistorisches Museum Basel, Switzerland

ZMHB Museum für Naturkunde der Humboldt-Universität, Berlin, Germany

MCSN Museo Civico di Storia Naturale "Giacomo Doria", Genova, Italy

DSTA Dipartimento di Scienze e Tecnologie Agroambientali, Alma Mater Studiorum Università di Bologna, Italy (formerly Istituto di Entomologia "Guido Grandi" de 1’Università)

CAS personal collection of Andreas Schulz, Leverkusen, Germany

The samples constituting the new records of Tetramorium forte listed below are deposited in CAS, some specimens will be transferred to MHNG, NHMB, MCSN and the Hungarian Natural History Museum, Budapest, Hungary.

\section{Measurements}

All measurements in this study were taken using a Zeiss Stemi SR stereo microscope equipped with an ocular graticule, at a maximum magnification of 250x. The data are presented as mean \pm standard deviation, with minimum and maximum value in brackets.

The following measurements were taken:

HL Maximum head length in median line. Both anterior and posterior outline of head must be in focus. Excavations of preoccipital margin and/or clypeus reduce HL.

HW Maximum head width above the eyes.

HS Head size - the arithmetic mean of HL and HW, used as a less variable indicator of body size.

SL Maximum straight line scape length, excluding the neck and basal condyle. To obtain the real maximum, a frontal to dorsal viewing position is necessary.

2FL Maximum length of second funiculus segment, only measured in males.

ED Maximum diameter of eye in dorsal view, only measured in males.

ML Mesosoma length. This is measured in lateral view from the frontalmost point of the anterior pronotal slope to the caudalmost portion of the propodeum ("Weber's length").

MW Maximum mesosoma width. This is measured in dorsal view at the widest part of the pronotum (workers) or constitutes the maximum width of scutum (gynes and males).

PSL Propodeal spine length, measured in workers and gynes. In dorsocaudad view, the tip of the measured spine, its base, and the center of the concavity between the spines must all be in focus (Fig. 1: points 1, 2 and 3). Using a cross-shaped ocular 
graticule, point 1 is placed along the vertical scale, point 3 along the horizontal scale. The spine length is measured as the distance from point 1 to point 2 . We measured always the right spine.

We did not calculate the often used propodeal spine index, measured in lateral view, which is the distance from the propodeal spiracle to the spine tip divided by the distance of the spiracle to the posterior border of the propodeum. It is nearly impossible to focus exactly, and to find the midpoint of the rounded concave border. Also we believe that the spiracle is very variable in its position, which does not relate to the propodeal spine length.

PEL Petiole length, measured in workers and gynes. The maximum length of the petiolar node is measured in dorsal view from the anterior notch close to the propodeum to the articulation with the postpetiole. Both points must be in focus.

PEW Maximum width of petiole in dorsal view.

PEH Petiole height, measured in workers and gynes. The maximum height of the petiolar node is measured in lateral view from the highest (median) point of the node to the ventral outline. The ventral outline has always a short concave part, which is the ventral measuring point.

PPL Maximum length of postpetiole in dorsal view, only measured in workers.

PPW Maximum width of postpetiole in dorsal view.

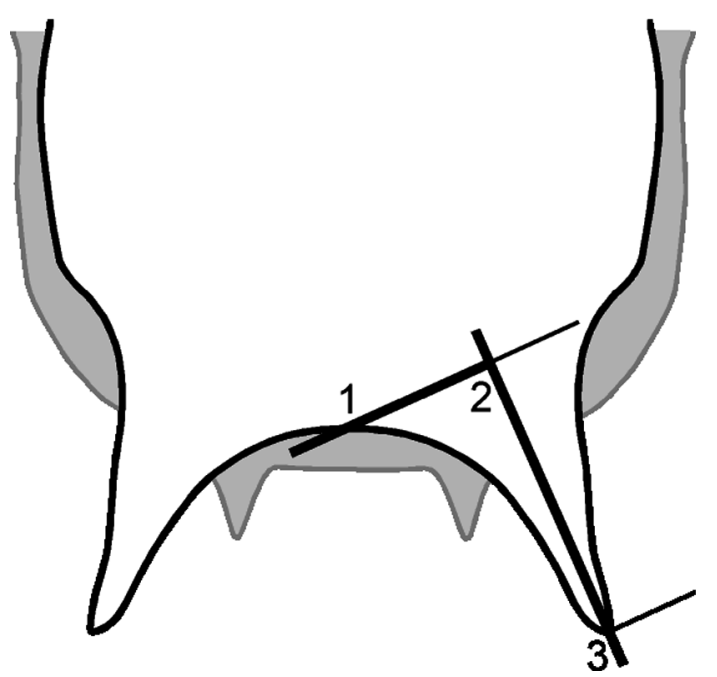

FIGURE 1. Measurement method for propodeal spine length (PSL) in ant workers using a crossshaped ocular graticule, dorsocaudal view. Points 1, 2 and 3 must be in focus.

The indices given in addition to the measurements are the following: HW/HL, SL/HS, SL/2FL, HS/ML (in gynes only), MW/ML, PSL/ML, PEH/PEL, PEW/PEL, PEW/HS, PPL/PPW, PPW/HS, PEW/PPW. We also calculated two indices which give a dimension of waist width in relation to body size: WI-A $=\mathrm{PEW}+\mathrm{PPW} / 2 \mathrm{xML}$; WI-B $=\mathrm{PEW}+\mathrm{PPW} /$ $2 \mathrm{xHS}$, this latter being useful only in workers. 
The photographic images presented here (Figs 2-20) were taken using a digital camera (JVC KY-70B) attached to a Leica Z6 APO stereo microscope. The microscope was equipped with a Z-stepper (Syncroscopy, Synoptics Ltd.) to enable the generation of usually 100 images in different focus layers from which subsequently a montage image was computed using the software AutoMontage Pro 5.02.0096 (Synoptics Ltd.). Montage images were enhanced (Photoshop 7.0, Adobe Systems Inc.) by removing inessential structures out of focus as well as artefacts caused by the montage process.

\section{Tetramorium forte Forel, 1904}

(Figs 2-6, 11, 16)

Tetramorium caespitum var. forte Forel, 1904[a]

Tetramorium caespitum ssp. caespitum var. hispanicum Emery, 1909 (name unavailable: ICZN $\S$ 45.5.)

Tetramorium caespitum var. ruginode Stitz, 1917: syn. nov.

Tetramorium caespitum var. hispanicum Bondroit, 1918 (synonymy with T. ruginode Stitz: Collingwood 1978, priority incorrectly given)

Tetramorium hispanicum Emery[sic]: Bondroit 1920

Tetramorium caespitum var. grandis Forel: Santschi 1921a (lapsus calami)

Tetramorium caespitum st. maura var. tingitana Santschi, 1921[b] (name unavailable: ICZN § 45.5.)

Tetramorium caespitum st. ferox var. marocana Santschi, 1921[c] (name unavailable: ICZN § 45.5.) Tetramorium maurum st. tingitanum Santschi, 1929: syn. nov.

Tetramorium ferox var. marocanum Cagniant, 1964 (name unavailable: ICZN § 45.6.3.)

Tetramorium maroccanum De Haro \& Collingwood, 1994: syn. nov.

Tetramorium ruginode Stitz: Bolton 1995

Material examined

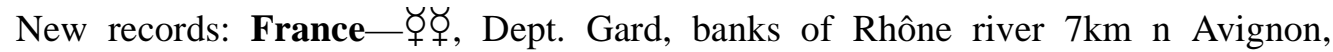
03.V.1992, leg. A. Schulz; ̧ㅜ, 우오, Dept. Vaucluse, banks of Rhône river near Avignon, 100m, 05-11.V.1992, leg. A. Schulz; ఫ̧ఛ, Dept. Hérault, Bois Noir n of Vailhauquès, ca. 15km nw Montpellier, 21.III.1995, leg. Windschnurer; ఫ̧ధ, Dept. Bouches-du-Rhône, St.Martin-de-Crau, ca. 12km e Arles, 23.III.1995, leg. Windschnurer; ఫॄఫ, Dept. Loire, above Malleval, VI.2002 and 02.V.2003, leg. R. Güsten. Spain—ఫ̧, Prov. Badajoz, Presa, near Embalse de Orellana, 22.I.1989, leg. D. Wrase; ఫॄఝ, S side of Sierra Nevada, 2200m, 06-18.V.1991, leg. A. Schulz; ఫॄ, Prov. Cádiz, Sierra Ubrique, between Benaocaz and Grazalema, 28.VIII.1991, leg. A. Buschinger \& P. Douwes; 하, 우 ㅇ, Prov. Granada, Sierra Nevada, rd GR 420, ca. 3rkm nw Sierra Nevada, ca. 1900m, 22.V.1995, leg. T. Aßmuth \& M. Sanetra; 항, 우오, Prov. Jaén, se Desfiladero de Despeñaperros, Puerto de los Jardines, 870m, 26.V.1995, leg. T. Aßmuth \& M. Sanetra; 항, 우우, ox $0^{x}$, Prov. Cuenca, ca. 2rkm e Villalba de la Sierra, ca. 20km n Cuenca, ca. 1200m, 26.V.1995, leg. T. Aßmuth \& M. Sanetra; ఫॄ, Prov. Cuenca, 2rkm n rd Beamud-Buenache, dir. Embalse de la Toba ne Cuenca, ca. 1400m, 27.V.1995, leg. T. Aßmuth \& M. Sanetra; 하, 우오, Prov. Teruel, 
Sanetra; ‘̧̧, Prov. Cordoba, Sierra de Hornachuelos, Cortijo de Spinola, 23.II.1999, leg. D. Wrase; $\not \varnothing \not$, Com. de Madrid, Boadilla del Monte, ca. 10km w Madrid, 25.II.1999, leg. D. Wrase; ఫॄ, Prov. Toledo, Quero, 08.III.1999, leg. D. Wrase. Portugal—ఫ̧, Distr. Viseu, Caldas da Felgueira, 600m, 22.VI.2000, leg. A. Schulz \& K. Vock; 항, 우우, ơ $0^{x}$, Distr. Guarda, Serra da Estrela, n slope of Torre, 1500m, 23.VI.2000, leg. A. Schulz \& K. Vock; ̧ㅜ, 우오, Distr. Castelo Branco, nr. Monsanto, 400m, 25.VI.2000, leg. A. Schulz \& K. Vock; ఫ̧ధ, Distr. Viseu, Serra de Montemuro, 1100-1300m, 26.VI.2000, leg. A. Schulz \& K. Vock; ఫ̧૪ఢ, Distr. Bragança, nr. Macedo de Cavaleiros, 600m, 27.VI.2000, leg. A. Schulz \& K. Vock; 하, 우우, ox $0^{x}$, Distr. Bragança, Parque natural de Montesinho, 700-900m, 29.VI.2000, leg. A. Schulz \& K. Vock; 후, 우우, ơ $0^{x}$, Distr. Bragança, Parque natural de Montesinho, 700-800m, 30.VI.2000, leg. A. Schulz \& K. Vock; ఫð, Distr. Bragança, Parque natural de Montesinho, 1000-1300m, 01.VII.2000, leg. A. Schulz \& K. Vock. Morocco- $\not \Varangle$, , 우, Reg. Ifrane, Moyen Atlas, rd 3325, 6rkm n rd S 309, 6rkm se Ifrane, ca. 1800m, 25.IV.1995, leg. R. Güsten, M. Sanetra \& R. Schumann; ఫ̛̣, Reg. Meknès, Moyen Atlas, rd S 303, ca. 24rkm s Aïn Leuh, ca. 1300m, 12.V.1995, leg. T. Aßmuth, R. Güsten, M. Sanetra, A. Schulz \& R. Schumann; ఫॄర్, Reg. Meknès, Moyen Atlas, rd 3211, 14 rkm n rd 3485, ca. 40rkm s Aïn Leuh, ca. 1100m, 12.V.1995, leg. T. Aßmuth, R. Güsten, M. Sanetra, A. Schulz \& R. Schumann; ఫ̛ఫ, Reg. Kénitra, Forêt de la Mamora, 2 rkm n Aïn-Johra, 100m, 19-20.V.1995, leg. T. Aßmuth, M. Sanetra \& A. Schulz; ఫ̛̣, Moyen Atlas, Reg. Meknès, Aguelmame Azigza, 1500m, 19.II.1999, leg. D. Wrase.

Other examined specimens: $1 \not{q}$, lectotype of $T$. caespitum forte Forel (hereby designated, Fig. 2): „T. caespitum L. ఫ v. forte Forel, type, Albaron Camargum / Lectotype Poldi 74 / Lectotypus Tetramorium caespitum forte Forel des. R. Güsten, A. Schulz \& M. Sanetra 2005“ (MHNG, together with 2 paralectotype ఫॄ孔 on same pin, lectotype marked by red cardboard square); 34 paralectotype $\not \Varangle$, Albaron (Camargue) (MHNG, 2 of these on same pin as lectotype); 2 paralectotype $\not \varnothing$, , same data as previous (MCSN); 3 paralectotype $\not \varnothing$, , same data as previous (NHMB); 2 paralectotype $\not \varnothing$, , same data as previous (DSTA); 11 ఢ̧, FRA, Camargue (MHNG); 3 ఢఢ, same data as previous (NHMB); 1 ఛ, same data as previous (DSTA); 5 ఛఢ, FRA, Albaron, 23.I.1925, leg. A. Chobaut (DSTA); 5 ఛఢ, FRA, Banyuls, leg. Saulcy (MCSN); 1 우, FRA, Var, Cavalairesur-Mer, VI.1922, leg. L. Berland (NHMB); 6 фఫ, syntypes of T. caespitum ruginode Forel: „Spanien, Cordova, Lehmann / Tetramorium caespitum L. v. ruginode Stz.[this label only with one of the syntypes] / Type / Zool. Mus. Berlin" (ZMHB); 5 ఫॄ, , POR, Viana Castells (DSTA); 1 ф, ESP, Barcelona, Certellas, VIII.1921, leg. Xaxars (DSTA); 24

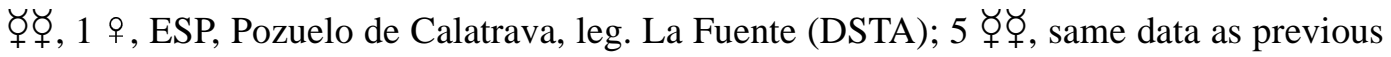
(MCSN); 1 ఢ, same data as previous (NHMB); 1 ఛ, ESP, Venta de Cardeñas, 27.VII.1879, leg. L. Bleuse (MCSN); 1 ఛ, ESP, Chamartín, 15.IV.1900 (MCSN); 4 ఛఢ, ESP, Puig, 13.I.1923 (MCSN); 4 ఛఛ, ESP, Montsiak, 15.I.1923 (MCSN); 1 ఛ, ESP, Cuenca, 
Belinchón, 08.VII.1925, leg. J.M. Dusmet (NHMB); 3 ఫ̛ఫ, 1 q, ESP, Villalba near Madrid, 28.III.1926, leg. H. \& H. Lindberg (NHMB); 2 ఫఫ, ESP, Sta Morena Sta Helena, 04-08.IV.1926, leg. H. \& H. Lindberg (NHMB); 1 [not + as stated by Emery 1909], lectotype of T. caespitum hispanicum Bondroit (hereby designated): ,Espagne Per[?] / Lectotypus Tetramorium caespitum hispanicum Bondroit des. R. Güsten, A. Schulz \& M. Sanetra 2005" (MCSN); 1 paralectotype $\Varangle$ (of T. c. hispanicum), same data as previous (MCSN); 2 paralectotype $\Varangle \Varangle$ (of T. c. hispanicum), leg. Cabrera (MCSN, together with 1 paralectotype $\zeta$ of T. c. hispanicum on same pin which is not T. forte); 1 paralectotype $\zeta$

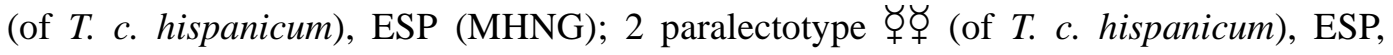
Carmona (DSTA); 1 우, lectotype of $T$. maurum tingitanum Santschi (hereby designated): „Maroc, Rabat, Thery / T. caespitum st maura v. tingitana, Santschi det. 1920 / Naturhist. Museum Basel / Sammlung Dr. F. Santschi, Kairouan / Lectotypus Tetramorium maurum tingitanum Santschi des. R. Güsten, A. Schulz \& M. Sanetra 2005“ (NHMB, together with paralectotype + on same pin, lectotype marked by red cardboard square); 1 paralectotype ㅇ (of T. $m$. tingitanum), MAR, Rabat, leg. A. Théry (NHMB, on

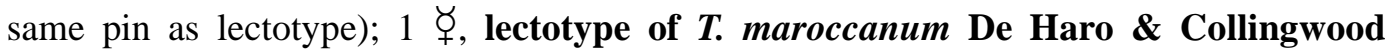
(hereby designated): „Aïn Leuh 103 / 17 / 41[?] / Tetramorium caespitum v. marocane Sants., Santschi det. 19 / Sammlung Dr. F. Santschi, Kairouan / Naturhist. Museum Basel / Lectotypus Tetramorium maroccanum De Haro \& Collingwood des. R. Güsten, A. Schulz \& M. Sanetra 2005" (NHMB); 1 paralectotype $\not$ (of T. maroccanum), MAR, Aïn Leuh (NHMB); 1 భ, MAR, Aïn Leuh, leg. A. Théry (NHMB); 2 ఫ̛, MAR, Rabat, leg. A. Théry (NHMB); 1 ఛ, MAR, Tanger, 1901, leg. G. Buchet (NHMB); 2 ఛ̧, MAR, Larache, III.1907 (NHMB); 1 ఛ, MAR, Ben-Slimane (formerly Boulhaut), leg. A. Théry (NHMB); 2 ఫ̛, MAR, Khénifra near Azrou, leg. A. Théry (NHMB); 11 ఛ̧, MAR, Forêt de Zaer (DSTA).

\section{Description of worker}

Measurements and indices ( $\mathrm{n}=34)$ : HL $0.824 \pm 0.057(0.725-0.936) \mathrm{mm}$, HW 0.783 $\pm 0.059(0.680-0.906) \mathrm{mm}$, HS 0.804 $\pm 0.056(0.702-0.921) \mathrm{mm}$, SL 0.631 $\pm 0.038(0.563-0.728) \mathrm{mm}$, ML 0.986 $\pm 0.111(0.831-1.194) \mathrm{mm}$, MW 0.529 $\pm 0.046(0.456-0.637) \mathrm{mm}$, PSL 0.104 $\pm 0.016(0.076-0.143) \mathrm{mm}$, PEL 0.328 $\pm 0.033(0.247-0.385) \mathrm{mm}$, PEW 0.290 $\pm 0.030(0.219-0.342) \mathrm{mm}$, PEH 0.271 $\pm 0.026(0.238-0.323) \mathrm{mm}$, PPL 0.208 $\pm 0.017(0.171-0.238) \mathrm{mm}$, PPW 0.335 $\pm 0.037(0.257-0.404) \mathrm{mm}$, HW/HL 0.951 $\pm 0.022(0.912-1.020)$, SL/HS 0.786 $\pm 0.026(0.727-0.840)$, MW/ML 0.560 $\pm 0.032(0.509-0.675)$, PSL/ML 0.110 $\pm 0.012(0.085-0.130)$, PEH/PEL 0.826 $\pm 0.048(0.750-1.019)$, PEW/PEL 0.868 $\pm 0.078(0.742-1.192)$, PEW/HS 0.360 $\pm 0.019(0.311-0.402)$, PPL/PPW 0.622 $\pm 0.044(0.553-0.688)$, PPW/HS 0.419 $\pm 0.021(0.365-0.466)$, PEW/PPW 0.860 $\pm 0.044(0.813-1.033)$, WI-A 0.322 $\pm 0.019(0.269-0.359)$, WI-B $0.390 \pm 0.018(0.338-0.430)$. 


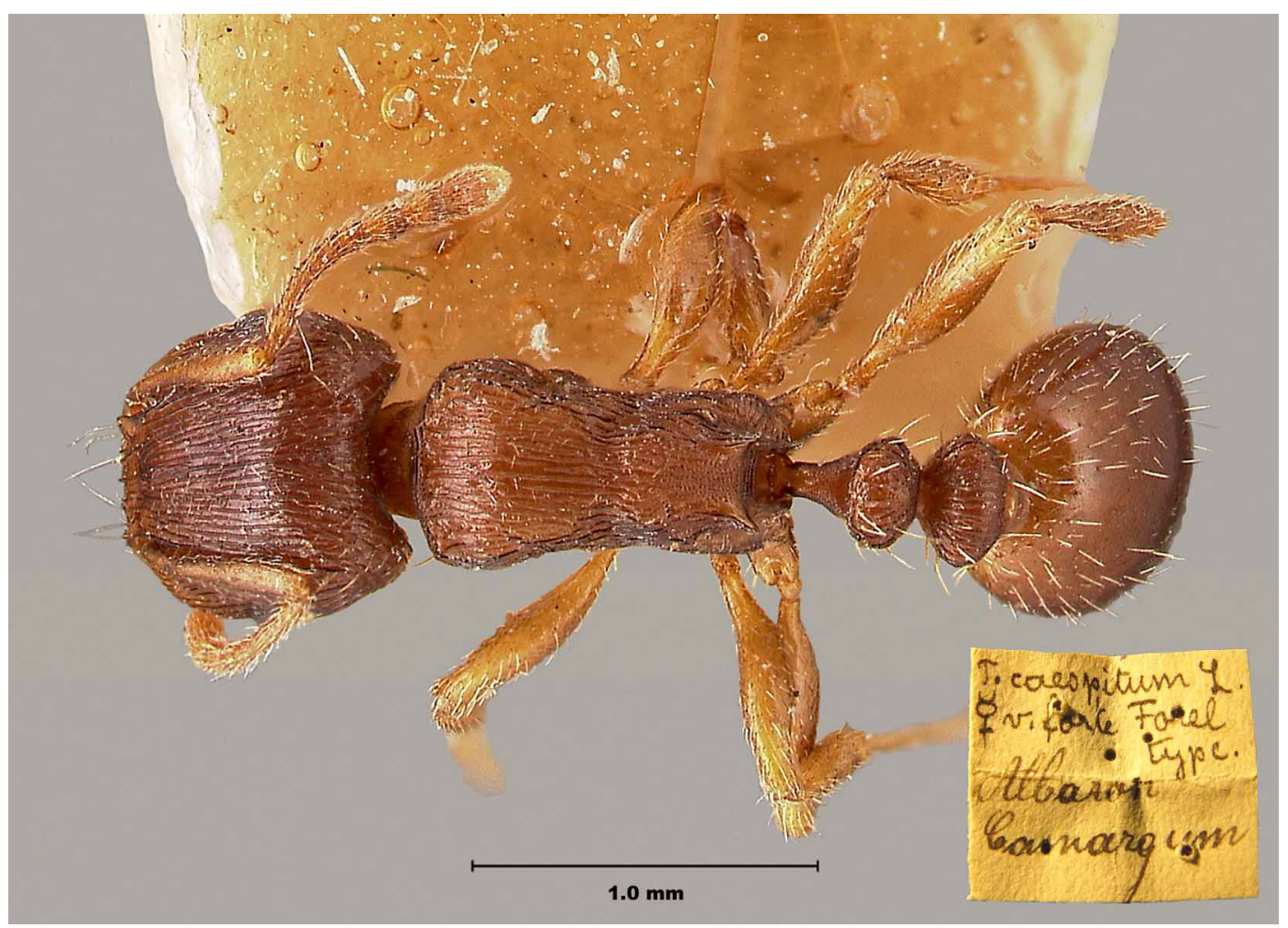

FIGURE 2. Lectotype worker of Tetramorium forte Forel, 1904 from Albaron (France, Camargue) in dorsal view, with original determination and locality label in A. Forel's handwriting.

Larger Palaearctic Tetramorium worker with subquadrate head. Preoccipital margin nearly straight to concave, genae more or less straight, outlines convergent (Fig. 11). Head widest behind the eyes. Mesosoma robust, broad, with pronounced pronotal angles (Fig. 2). Mesopropodeal suture shallowly depressed. Propodeal spines moderately long and straight. Petiole robust, node in lateral view rather rounded, outline anterior of node concave. Petiole and postpetiole broad in relation to mesosoma, postpetiole with laterally prominently protruding angles (Figs 2,16). Dark brown to blackish, appendages lighter, orange-brown. Head, dorsal parts of mesosoma, petiole and postpetiole entirely carinate or rugose. Frontal area of head with 14-16 even rugae which diverge slightly towards the preoccipital margin, converging into a conspicuously arcuate pattern in lateral view (see Schulz 1996, p. 407). Genae and surface of occipital corners rugose (Fig. 11). Dorsal surface of head with reticulate microsculpture, but with few more conspicuous anastomoses between principal rugae. Ventral head surface longitudinally striate without any microsculpture. Scapes usually smooth and shinning, sometimes with diffuse 
microsculpture, and with an inconspicuous anterio-dorsal carina at the base which may grade into the trace of a transverse extension but not into a conspicuous dorsally projecting flange. Dorsal surface of mesosoma rugose with variably developed reticulate microsculpture, on the propodeum evenly and roughly reticulate, especially between the spines. Dorsal part of petiole and postpetiole longitudinally to concentrically, often rather irregularly rugose with reticulate microsculpture, no weakening of sculpture on dorsalmost surfaces (Fig. 16). Ventral parts of petiolar nodes heavily reticulate. Polygonal microsculpture on the first gaster tergite never absent, rarely covers the whole surface of the tergite (in some Moroccan specimens). On the anteriormost part of the tergite, this microsculpture can appear striated in some specimens. Frequency of the latter feature within the same nest series increases towards the south of the species' range.

\section{Description of gyne}

Measurements and indices ( $\mathrm{n}=23)$ : HL 1.064 $\pm 0.073(0.842-1.293) \mathrm{mm}$,

HW 1.127 $\pm 0.096(0.891-1.391) \mathrm{mm}$, HS 1.096 $\pm 0.080(0.866-1.330) \mathrm{mm}$, SL 0.791 $\pm 0.044(0.634-0.861) \mathrm{mm}$, ML 1.762 $\pm 0.101(1.391-1.879) \mathrm{mm}$,

MW 1.082 $\pm 0.074(0.830-1.196) \mathrm{mm}$, PSL 0.147 $\pm 0.022(0.105-0.181) \mathrm{mm}$, PEL 0.467 $\pm 0.029(0.380-0.504) \mathrm{mm}$, PEW 0.559 $\pm 0.047(0.418-0.618) \mathrm{mm}$, PEH 0.460 $\pm 0.034(0.371-0.518) \mathrm{mm}$, PPW 0.711 $\pm 0.054(0.556-0.817) \mathrm{mm}$, HW/HL 1.060 $\pm 0.060(1.000-1.326)$, SL/HS 0.723 $\pm 0.034(0.602-0.763)$, HS/ML 0.622 $\pm 0.028(0.581-0.727)$, MW/ML 0.614 $\pm 0.019(0.568-0.653)$, PSL/ML 0.083 $\pm 0.011(0.062-0.102)$, PEH/PEL 0.984 $\pm 0.059(0.902-1.111)$, PEW/PEL 1.194 $\pm 0.097(1.000-1.383)$, PEW/HS 0.511 $\pm 0.037(0.421-0.569)$, PPW/HS 0.650 $\pm 0.045(0.525-0.712)$, PEW/PPW 0.787 $\pm 0.042(0.630-0.855)$, WI-A $0.360 \pm 0.017(0.324-0.392)$.

Medium-sized Palaearctic Tetramorium gyne, generally with rather robust appearance. Head with rather rounded preoccipital corners and straight to slightly convex, somewhat convergent genal outlines (Fig. 3). Scape relatively short and broad. Mesosoma short and robust, with flat (not bulging) dorsal outline. In dorsal view the pronotal angles are fully visible (Fig. 5). Propodeal spines broadly attached, triangular with pointed tips, orientation subcaudate. Petiole and postpetiole very wide, lobe-like, the petiole medially emarginated. First gaster tergite with at least a few erect hairs. Colour as in workers. Frons rugose, the rugae divergent and curving towards the occipital corners with little or no anastomosing (Fig. 3). Genae rugose, ventral head surface longitudinally striate. On the genae and near the occipital corners, a fine reticulate microsculpture occurs between the main rugae. Sides of mesosoma and petiolar segments mainly longitudinally carinate, restricted parts only rugose. In dorsal view, pronotum with rugose sculpture, mesonotum longitudinally rugose but more weakly so laterally, with a very small smooth and shining spot anterio-medially, scutellum rugose except for narrow smooth median part (Fig. 5). Sculpturing between the 
spines variable, principally longitudinally rugose. Sculpture of dorsal surface of waist segments also variable, diffusely rugose to rugulose, to concentrically striate. Individuals with more pronounced sculpturing have the rugose portion more strongly developed. Polygonal microsculpture covers small spots on the first gaster tergite, appearing longitudinally striate on the anterior part $(0.150-0.250 \mathrm{~mm})$ of the tergite.

Descriptions of $T$. forte gynes have been published by Bondroit (1920, as $T$. hispanicum), Santschi (1921b, as "T. caespitum st. maura var. tingitana"), Santschi (1932, as "T. caespitum st. hispanicum var. ruginodis") and Cagniant (1997, as T. ruginode marocana), the latter providing a drawing of the petiolar segments. The gynes from Spain studied by Santschi (1932) are present in NHMB.
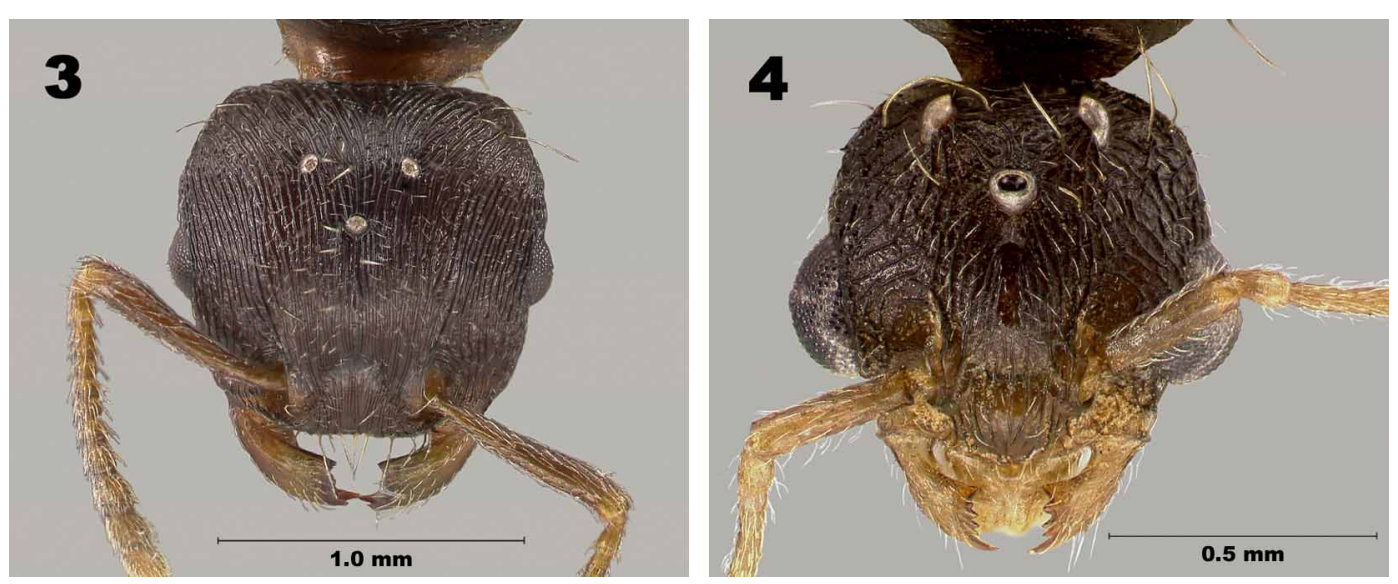

FIGURES 3-4. Tetramorium forte, full-face view of heads. 3, gyne; 4, male. See Appendix B for provenance of specimens depicted.

\section{Description of male}

Measurements and indices ( $\mathrm{n}=22)$ : HL 0.738 $\pm 0.019(0.702-0.770) \mathrm{mm}$, HW 0.752 $\pm 0.043(0.687-0.891) \mathrm{mm}$, HS 0.745 $\pm 0.025(0.695-0.800) \mathrm{mm}$, SL $0.344 \pm 0.011(0.323-0.361) \mathrm{mm}$, 2FL 0.406 $\pm 0.018(0.361-0.428) \mathrm{mm}$, ED 0.278 $\pm 0.012(0.257-0.304) \mathrm{mm}$, ML 2.028 $\pm 0.064(1.891-2.135) \mathrm{mm}$, MW 1.210 $\pm 0.064(1.098-1.318) \mathrm{mm}$, PEW 0.482 $\pm 0.048(0.390-0.589) \mathrm{mm}$, PPW 0.637 $\pm 0.046(0.570-0.722) \mathrm{mm}$, HW/HL 1.020 $\pm 0.059(0.959-1.255)$, SL/HS 0.462 $\pm 0.022(0.421-0.501)$, SL/2FL 0.847 $\pm 0.041(0.778-0.925)$,

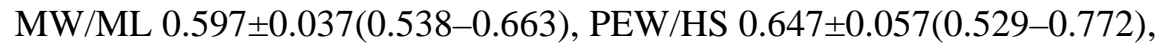
PPW/HS 0.854 $\pm 0.051(0.778-0.934)$, PEW/PPW 0.758 $\pm 0.056(0.661-0.848)$, WI-A $0.276 \pm 0.017(0.236-0.311)$.

Small Palaearctic Tetramorium male, with broad head and relatively large eyes (Fig. 4). Mesonotum and scutellum bulging. Propodeal spines well visible, but short and more or less triangular, tooth-like. Petiole and postpetiole very broad (Fig. 6), petiole on each 
side with two laterally oriented processes and a distinctly emarginate median part. Isolated erect hairs on first gaster tergite. Colour dark brown, appendages yellowish orange. Sculpture on head, mesosoma and waist dense. Head largely rugoreticulate (Fig. 4), pronotum and lateral parts of mesosoma chiefly longitudinally striate with reticulate microsculpture, mesonotum longitudinally to concentrically striate but with extensive parts laterally and anterio-medially smooth and shining (Fig. 6). Scutellum completely striate, propodeum diffusely striate to reticulate, waist segments reticulate, gaster without sculpture.

The male of $T$. forte had hitherto only been described by Cagniant (1997, under the name $T$. ruginode marocana), based on one specimen. This work included detailed drawings of genitalic characters.
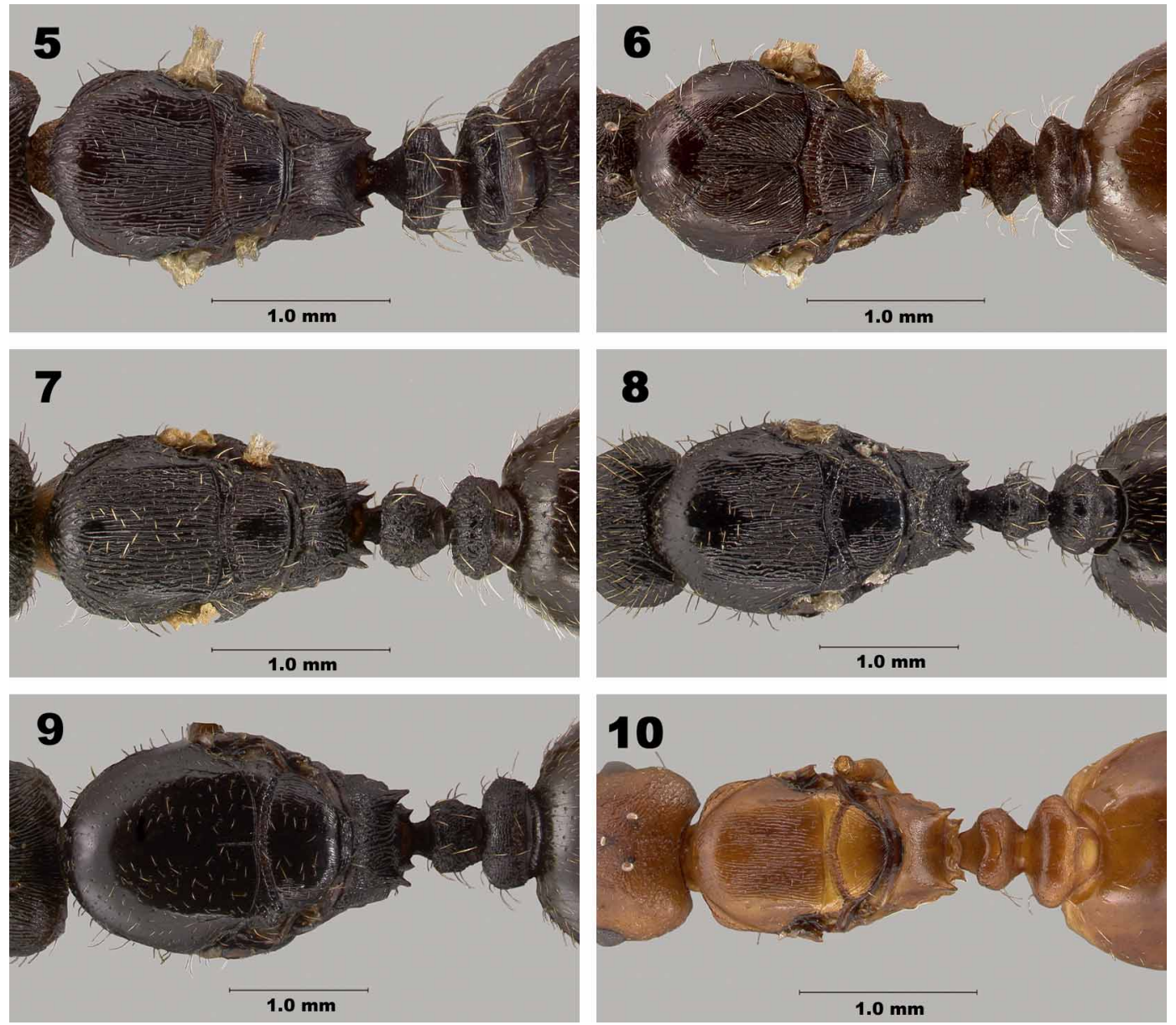

FIGURES 5-10. Tetramorium gynes and male, dorsal views showing mesosoma and waist. 5, gyne of $T$. forte; 6, male of $T$. forte; 7, gyne of T. chefketi; 8, gyne of T. moravicum; 9, gyne of $T$. caespitum s.l.; 10, gyne of T. meridionale. See Appendix B for provenance of specimens depicted. 


\section{Selection of the lectotype}

The incorporation of a western Mediterranean and an eastern European taxonomic species under the nominal taxon Tetramorium forte dates back to the original description and has persisted until the present. The type series on which Forel (1904a) based his new taxon was both varied and ambiguously delimited by him. He included workers from several localities in southern France and one series of workers from the Crimean Peninsula. Gynes and males from Crimea and Transcaucasia were described; the latter were only doubtfully assigned to the new taxon. The author made conflicting statements in different sections in the description whether the sexuals from Crimea were definitely or conditionally included. Also, after describing those males and gynes, only two gynes from Crimea and one from Transcaucasia were actually listed among the specimens, but no males. Because of the reservations in assigning the sexuals to the new taxon, these are not to be considered syntypes (ICZN § 72.4.1.). According to Radchenko (1992), the sexuals in question, preserved at the Zoological Institute of the Russian Academy of Sciences, St. Petersburg, Russia (ZISP), are referable to T. caespitum (Linnaeus, 1758). The syntype series to be appraised thus consists of at least 55 workers from 4 localities in southern France (mainly at MHNG, but some also at MCSN, DSTA and ZMHB, more may be detected in other collections) along with 15 workers from Alušta, Crimea, Ukraine, of which 11 are currently deposited at ZISP (Csősz et al., unpubl.).

As a consequence of the description of the taxon from widely scattered localities preserved at different institutions, researchers in western and eastern Europe have tended to use T. forte for species from their respective areas of investigation, without addressing the inconsistency of the type series. For example, Casevitz-Weulersse (1990a) and López (1991) referred to subsets of Forel's original specimens from southern France as types, even mentioning a putative "lectotype", while Radchenko (1992) cited as syntypes only the specimens from Crimea and Transcaucasia, disregarding the French part of the type series. No lectotype of $T$. forte has ever been formally designated.

To terminate this ambiguous and instable nomenclatural situation, we decided to have the western European taxonomic species bear the name T. forte which is represented in the type series by numerous syntypes from Albaron (Camargue, France). As will be detailed below, this choice is the one most furthering stability and universality in nomenclature, following the predominant usage in the ant literature of the past 100 years including recent important phylogenetic studies. And it is also the interpretation most consistent with the original author's intentions, because his statement of the postpetiole being about twice as wide as long only applies, in approximation, to the chosen taxonomic species among those represented in the type series (Fig. 2, compare with Figs 16-18 and 20). This indicates that Forel (1904a) had that species in mind (which is also clearly the predominant one among syntypes) when he drafted the description. As the lectotype of T. forte (Fig. 2), we herewith choose one of three syntypes on a pin labeled „lectotype“ by B. Poldi in 1974 (without indicating the specimen), but not published. We have marked the lectotype by a 
red square with the indication "LT" attached to the cardboard triangle bearing the specimen. Presence of the lectotype in MHNG has also practical advantages for subsequent investigators, as the great majority of primary types of taxa described by A. Forel are preserved in that institution.

Numerous publications have used the name $T$. forte in the sense coinciding with our concept (e.g. Forel 1905; Bondroit 1918; Santschi 1921a, 1921c, 1937; Bernard 1967; Collingwood \& Yarrow 1969; Collingwood 1978; López 1991; Sanetra et al. 1994; Sanetra \& Buschinger 2000; Steiner et al. 2005; Schlick-Steiner et al. 2005). This includes all works of the past twelve years which for the first time elucidate phylogenetic relationships in the genus Tetramorium in western and central Europe. A lesser number of publications has applied the name T. forte to eastern European and Middle Eastern species (e.g. Wheeler \& Mann 1916; Agosti \& Collingwood 1987a, 1987b; Radchenko 1992; Atanassov \& Dlussky 1992, Arakelian 1994). However, the Tetramoriini of these parts of the Palaearctic are both very diverse and particularly little known, so that it is difficult to determine which concepts really form the basis for the mentioned usages of the name $T$. forte. It is likely that few, if any, refer exclusively to the taxonomic species to which the workers from Alušta (Crimea) in the syntype series of $T$. forte actually belong. According to current revisionary work (Csősz et al., unpubl.), T. chefketi Forel, 1911 and T. caespitum sarkissiani Forel, 1911, two names of equal priority, are available for that species, the former of which having also been used in recent taxonomic, faunistic and phylogenetic studies (Schulz 1996; Sanetra \& Buschinger 2000; Schulz \& Sanetra 2002; Schlick-Steiner et al. 2005; see also Appendix A). Thus it would have been a substantial disservice to nomenclatural stability to choose the lectotype of $T$. forte from the Alušta specimens.

It needs to be noted that a few publications, both old and recent, have used $T$. ruginode Stitz, 1917 as the name of the western Mediterranean species treated here (e.g. Menozzi 1926; Santschi 1932; Cagniant 1997; De Haro \& Collingwood 1997; Espadaler 1997a; Salgueiro 2002a), which would have become its valid name, had T. forte been formally stabilized for the eastern European species involved in the type series. However, the name most frequently in use for the western Mediterranean species in recent publications has been T. hispanicum Bondroit, 1918 (e.g. Acosta Salmerón et al. 1983; Ortiz \& Tinaut 1988; De Haro \& Collingwood 1988, 1991, 1992; Paiva et al. 1990; Tinaut 1991; Espadaler \& Suñer 1995; Cammell et al. 1996; Way et al. 1997; Molero-Baltanás et al. 1998; Reyes López \& García 2001), and that is definitely a junior synonym of T. ruginode (see in the following section). Many of the afore-mentioned authors wrongly credited the description of T. hispanicum to Emery (1909).

The use of $T$. ruginode and $T$. hispanicum for the species probably originated in deviant concepts for $T$. forte which were based at least in part on type studies disregarding the Albaron specimens (Casevitz-Weulersse 1974, 1990a, 1990b; López Gómez 1988; López 1991). Our investigations revealed that at least two other taxonomic species are represented among the French syntypes. Three workers each from Nice and Palavas (near 
Montpellier) are relatively robust and strongly sculptured specimens of $T$. caespitum sensu lato (see Appendix A). They probably belong to an as yet weakly defined species separate from T. caespitum (Linnaeus, 1758) which commonly occurs along Mediterranean coasts (Schlick-Steiner et al., 2006). Study of these syntypes was probably partly responsible for the recording of $T$. forte from Corsica (Casevitz-Weulersse 1990a, 1990b) and for its treatment as merely a variety (Casevitz-Weulersse 1974) or subspecies (Cagniant 1997) of T. caespitum. While the postpetiole is on average slightly wider in these specimens than in true $T$. caespitum, it is by far not twice as wide as long as mentioned in the original description of $T$. forte, and rugosity and microsculpture are much less developed than in the lectotype from Albaron. Six workers from Dieulefit (Dept. Drôme) do show that pronounced sculpturing but the postpetiole is in no way shorter or wider than e.g. in $T$. caespitum. These workers belong to T. moravicum Kratochvil, 1941, a chiefly eastern European species described from the Czech Republic (Novak \& Sadil 1941) which only recently has been found to occur in southeastern and eastern France (Schlick-Steiner et al., in press; Güsten, unpubl.; see Fig. 22). The addition of these specimens to the syntype series by Forel (1904a) can be ascribed to the incomplete understanding of variability and critical characters in the genus at the time.

\section{Synonymy}

Upon stabilization of the name $T$. forte for a western Mediterranean ant species, three species-group names in the genus Tetramorium can be firmly established as its junior synonyms: T. ruginode Stitz, 1917 (with its junior synonym T. hispanicum Bondroit, 1918), T. maurum tingitanum Santschi, 1929 and T. maroccanum De Haro \& Collingwood, 1994. In contrast, three other names are recognized to have incorrectly been proposed earlier as junior synonyms of T. forte: T. caespitum pyrenaeicum Röszler, 1936, T. moravicum Kratochvil in Novak \& Sadil, 1941 and T. taurocaucasicum Arnol'di, 1968. An oddity is T. silvestrianum Emery, 1924, which was claimed to be a synonym of T. forte by Collingwood and Yarrow (1969), Collingwood (1978) and López (1991) although it belongs in fact to the genus Myrmica Latreille (see Appendix C). Santschi (1921a) cited a "var. grandis For.", with "Camargue" as the type locality, a lapsus calami for "fortis" probably caused by the similar meaning of the two words in Latin. Further on in the same paper, the correct name is used. The same error occurs on labels of several North African specimens of T. forte in F. Santschi's collection in NHMB.

\section{Newly established synonyms}

T. ruginode Stitz, 1917 (with T. hispanicum Bondroit, 1918):

The synonymy of $T$. ruginode and $T$. hispanicum with $T$. forte as defined above is straightforward. Types of both taxa originate from Spain, its main area of distribution, and López (1991), Sanetra and Buschinger (2000) and this study have convincingly shown that 
not more than one species with similar morphological features occurs there. Some misunderstanding was caused by Emery (1909) who allegedly described only the gyne morph of "T. caespitum caespitum var. hispanica", as accepted by Bondroit (1918) and other subsequent authors. However, the inclusion of "hispanica" in the worker key in Emery (1909) as well as the study of syntypes in several collections made it clear that a misprint of the worker icon as a female icon had occurred, and in fact only workers had been available. Thus, the character Emery (1909) gave to differentiate his new variety from var. forte, namely the presence of fine striation on the gaster base, referred to workers. Nevertheless, as detailed below, this character does not have taxonomic value. Stitz (1917) also separated his new variety from $T$. forte only on uninformative characters such as worker size and roughness of rugosity on head and mesosoma.

Because of the scattering of the syntype series over several collections and its unknown extent, it was considered useful for nomenclatural stability and for further study to designate a lectotype of T. caespitum hispanicum Bondroit, 1918 from the two remaining specimens in Emery's original collection at MCSN. Bondroit (1918) made it clear that he had no additional specimens available. In the case of $T$. caespitum ruginode Stitz, 1917, there are six syntype workers at MZHB obviously originating from the same collection event so that the designation of a lectotype appeared superfluous.

\section{T. maroccanum De Haro \& Collingwood, 1994:}

We have studied numerous specimens from Morocco including types of $T$. maroccanum and in our opinion there are no reasons to separate them from T. forte. This is suggested also by allozyme (Sanetra \& Buschinger 2000) and mtDNA studies (SchlickSteiner et al., 2006). Cagniant (1997) proposed to uphold maroccanum as a subspecies (of T. ruginode), based on whitish instead of yellowish pilosity, and on reticulated, relatively distinct rugosity on the anterior part of the first gastral tergite in workers (as opposed to relatively weak or absent striation in the nominate subspecies). We could not confirm differing colouration of pilosity in the specimens studied. We did find, though, substantial individual variation in the polygonal microsculpture of the first gaster tergite in workers. Csősz (pers. comm.) confirms a geographical component to that variation with those from the north of the range usually much more weakly sculptured, although intracolonial variability is high. Gynes also have that microsculpture on the first gaster tergite, but differences along a north-south gradient are not observed. In males the first gaster tergite is never sculptured. The clinal geographic variation of a single surface sculpture character in only one morph seems to us no justification for retaining subspecific differentiation in $T$. forte.

T. maroccanum was inadvertently described by De Haro and Collingwood (1994) who did not realize that the infrasubspecific entity "T. caespitum st. ferox var. marocana" earlier proposed by Santschi (1921c) was an unavailable name (ICZN $§ 45.5$.). Following $\S$ 72.4.4., the type series of a species-group taxon made available by biographical 
reference consists of those specimens on which the unavailable name had been based, plus any additional specimens that the subsequent author had at his or her disposal when making available the name. As it is not fully clear which these latter may be in the case of T. maroccanum De Haro \& Collingwood, a lectotype is designated from those syntypes in NHMB labeled "Tetramorium caespitum v. marocanum" by F. Santschi, to provide a reliable basis for establishing the name as a junior synonym of $T$. forte.

T. maurum tingitanum Santschi, 1929:

The syntypes of T. maurum tingitanum described from Rabat (Morocco) posed a problem. Gynes were not distinguishable from North African T. forte, while workers grossly differed in being small, yellowish and not strongly sculptured, as is typical for $T$. semilaeve André, 1883 and related species. Most likely based on these workers, Cagniant (1997) had synonymized T. maurum tingitanum with T. biskrense Forel, 1904[b], a North African species similar in some respects to $T$. semilaeve. However, we have studied the syntypes of $T$. biskrense from eastern Algeria and we do not believe that the worker syntypes of T. maurum tingitanum belong to this species. They may be referable to $T$. maurum Santschi, 1918 (see Appendix A), but the occurrence of that species in Morocco needs to be confirmed. Even though gynes of true T. maurum are indeed quite similar to those of T. forte (see below), and gynes and workers in the type series of T. maurum tingitanum bear the same locality labels and may originate from the same collection event, we still deem it highly improbable that they represent the same species. Instead of upholding a questionable synonymy based on the workers, we decided to designate one of the two gynes as the lectotype of T. maurum tingitanum Santschi and synonymize this taxon with T. forte.

\section{Previously proposed synonyms}

T. moravicum Kratochvil in Novak \& Sadil, 1941:

Radchenko (1992) proposed the synonymy of T. moravicum with T. forte, an opinion also advocated by Atanassov and Dlussky (1992). This view was based on one hand on the consideration of only the Crimean specimens from the type series of T. forte, on the other hand on the belief that besides T. moravicum, which is frequent on the Crimean Peninsula, no other species with similar morphological features occurs there. It was later recognized (Radchenko et al. 1998; Csősz, pers. comm.) that the workers from Alušta in the T. forte type series are not conspecific with the similar species found in most parts of Crimea. Radchenko et al. (1998) consequently accepted T. moravicum again as a good species. Schlick-Steiner et al. (2005) demonstrated that T. rhenanum Schulz, 1996 is to be included in $T$. moravicum as a microgynous form.

T. taurocaucasicum Arnol'di, 1968:

Another taxon described from Crimea, T. taurocaucasicum Arnol'di, 1968, was also regarded as a junior synonym of $T$. forte by Radchenko (1992). The holotype of $T$. 
taurocaucasicum is conspecific to the Alušta workers (Csösz et al., unpubl.), so that upon the stabilization of $T$. forte for a western Mediterranean species, $T$. taurocaucasicum must be listed as a synonym of T. chefketi and T. caespitum sarkissiani (see Appendix A).

\section{T. pyrenaeicum Röszler, 1936:}

This taxon was initially described from Andorra as a subspecies of T. caespitum and elevated to species rank by Röszler (1951). Some authors have later considered it synonymous with T. forte (Collingwood \& Yarrow 1969; López 1991). The original description of T. caespitum pyrenaeicum was inadvertently published in a paper (Röszler 1936) projected to appear after Röszler (1937), which contains the more detailed intended original description. The latter makes it clear that $T$. pyrenaeicum cannot be identical to $T$. forte: the gynes are almost the size of $T$. caespitum s.l. gynes, and as in these, the mesonotum is completely smooth and shining. The petiolar nodes, however, are as broad as in T. forte, while the petiole bears a short projection medio-dorsally instead of a slight emargination. We do not know any Tetramorium species with these characters, neither from Andorra nor from Hungary and central Germany, whence a slight variety of $T$. pyrenaeicum was characterized by Röszler (1937). No syntypes of T. pyrenaeicum remain in its original depositories, the Muzeul Brukenthal, Sibiu, Romania (Pascu, in litt.; Markó \& Csősz 2002) and the Zoologisches Museum der Universität Hamburg, Germany (see e.g. Rabaglia 2005), and none have as yet been detected in other European collections which contain scattered syntypes of taxa described by P. Röszler. Tetramorium pyrenaeicum thus remains enigmatic for the time being.

\section{Phylogenetic relationships and similar species}

Tetramorium forte belongs to the caespitum-group of species in the sense of Bolton (1977), which is (except for some peripheral species) the only Palaearctic one out of 40 largely provisional species-groups defined by Bolton $(1976,1977,1979,1980)$ in the genus Tetramorium. Few studies have addressed phylogenetic relationships in this group and in particular the position of T. forte. Palomeque et al. (1989) studied the karyotype of T. forte, which proved to be of little interest for phylogeny as all Palaearctic Tetramorium species hitherto studied have a haploid chromosome number of $n=14$ with few differences in chromosome morphology (Lorite et al. 2000; Sanetra, unpubl.). Based on allozyme electrophoresis, Sanetra and Buschinger (2000) found T. chefketi (see Appendix A) to be very closely related to $T$. forte, a finding corroborated by mtDNA studies (Schlick-Steiner et al. 2005). The position of T. moravicum was ambiguous, as it constituted a clade with $T$. forte and T. chefketi in some but not all data analyses (Sanetra \& Buschinger 2000; Schlick-Steiner et al., 2006).

Tetramorium forte is a member of a morphologically defined assembly of species in which the workers are dark and strongly sculptured, with no unsculptured surface areas on 
the waist segments. While not all these species are necessarily closely related, the allopatric $T$. chefketi, found to be related to $T$. forte in phylogenetic studies, is also the most similar species. Tetramorium moravicum is also closely similar and sympatric with $T$. forte in southeastern France (see below). One other species sharing the lack of smooth and shining areas on the petiolar nodes, T. alternans Santschi, 1929 (see Appendix A), is sympatric with $T$. forte in North Africa. The other Tetramorium taxa sympatric with $T$. forte in Europe, which are T. caespitum s.l. (see Appendix A), T. semilaeve and $T$. meridionale, belong to other species complexes and show more divergent morphological characters. Tetramorium maurum (see Appendix A), which may be sympatric with T. forte in the Maghreb, is anomalous as the gynes are very similar, even though based on the workers the species should rather be assigned to a widely conceived $T$. semilaeve complex.

\section{Differentiation of workers}

In workers, $T$. forte is most readily distinguishable from other dark, strongly sculptured Palaearctic Tetramorium species by its wide petiolar nodes. While this is not as obvious as in gynes, the postpetiole shows a conspicuously angular lateral outline in dorsal view (compare Fig. 16 with Figs 17-19), and the values for WI-A and WI-B are larger while that for PPL/PPW is smaller than in the most similar species, with some overlap (Table 1).

Except for this character, workers of $T$. chefketi are very similar to $T$. forte, though the mesosoma is narrower (Table 1) and the sculpture overall more strongly rugose, particularly near the occipital corners where there is also some anastomosing of the rugae (Fig. 12). Tetramorium moravicum workers are also similar-they may be identified by a more prominent anterio-dorsal carina at the base of the scape than in $T$. forte and $T$. chefketi, which extends into a conspicuous dorsally projecting flange (Fig. 13). Also, in contrast to $T$. forte, the scape is reticulate or faintly longitudinally rugose in T. moravicum, and the occipital corners are quite prominent with the main rugae on the head running parallel throughout their length and not converging into an arcuate pattern in lateral view as in T. forte (see Schulz 1996, p. 407). Tetramorium alternans is a smaller species than $T$. forte (Table 1) with a lighter, reddish-brown colour. The scapes are shorter with a densely striate to granulate sculpture. While there are no smooth and shining spots on the waist segments, densely reticulate microsculpture predominates with only a sparse weak rugosity (Fig. 19). In this character, T. alternans recalls T. brevicorne Bondroit, 1918 from the Tyrrhenian Islands (see Sanetra et al. 1999) rather than T. forte, T. chefketi or $T$. moravicum.

Workers of $T$. caespitum s.l. strongly differ from those discussed before by conspicuous smooth and shining medial areas on the petiolar segments (which, however, may greatly vary in width), and the head surface has a much more weakly developed rugosity, appearing shining through the lack of microsculpture (Figs 15, 20). The waist segments are a lot narrower than in T. forte (Table 1). The workers of T. semilaeve, and many ill-defined species similar to it, are even more weakly sculptured, yellowish to light 
reddish-brown and much smaller than $T$. forte (nest means of ML always $<0.800 \mathrm{~mm}$, HS $<0.730 \mathrm{~mm}$ ). Workers of T. meridionale have petiole and postpetiole at least as broad as $T$. forte, but in other characters generally resemble $T$. semilaeve.

\section{Differentiation of gynes}

In gynes, $T$. forte is easily distinguished from $T$. chefketi, $T$. moravicum and $T$. alternans by the very broad waist segments (compare Fig. 5 with Figs $7-8$, see also Table 2).

Tetramorium chefketi gynes are otherwise very similar, particularly in dorsal surface sculpturing (Fig. 7), but the mesosoma is somewhat more slender (only slightly narrower numerically, Table 2) and the rugosity is more pronounced. The latter is most obvious on the head with a rugoreticulum developed near the hind margin, even extending anteriolaterally beyond the eyes (see Schulz 1996, p. 407), whereas few anastomoses between the longitudinal rugae are evident in T. forte (Fig. 3). Tetramorium moravicum gynes differ in the structure of the scape base in a similar way as workers do; in most populations they are much larger than $T$. forte but microgynes are the size of large $T$. forte gynes (Table 2). The only known gyne of $T$. alternans has the mesonotum more tapering anteriorly, and narrower (Table 2) than in T. forte and less than half of its surface (medio-posteriorly) is longitudinally rugose to striate.

The gynes of $T$. caespitum s.l. are much larger than those of $T$. forte (Table 2), which is associated with a relatively smaller head and a bulging mesonotum completely concealing the pronotal corners in dorsal view, and the mesosoma is smooth and shining over two thirds of its surface or throughout (Fig. 9). Tetramorium semilaeve gynes are also weakly sculptured (usually few shallow striae on the mesonotum), and are more lightly brownish than those of $T$. forte, while they are of similar size. Those of $T$. meridionale are even more yellowish, have a conspicuous transverse striation on the occipital margin and enlarged petiolar nodes though somewhat less than T. forte (Fig. 10).

Even though the workers of T. maurum are very dissimilar to those of T. forte and indicate the affiliation to a different species complex, the gynes surprisingly were found to be closely similar. No morphometric characters have been detected that reliably differentiate the gynes of the two species. However, T. maurum gynes are lighter in colour (reddish-brown), the dorsal border of the petiole is not emarginated medially, the rugae on the head are less pronounced, and a larger medial unsculptured surface (>50\%) occurs on the scutellum, sometimes small unsculptured areas are also present on the petiolar nodes.

\section{Differentiation of males}

In males, much as in gynes, $T$. forte is characterized by a wider petiole and postpetiole (WI-A: 0.236-0.311) than T. chefketi and T. moravicum (nest means of WI-A always < 0.240, compare also Schulz 1996, p. 412).

In most populations, T. moravicum males are larger (ML $>2.200 \mathrm{~mm})$ but where microgynes occur, the size is about the same as for $T$. forte males. In T. forte the scutellum 
zootaxa is clearly striate (Fig. 6), whereas $T$. moravicum has a more diffuse often striolo-reticulate 1310 sculpture with sometimes a shining median part. Tetramorium alternans males are unknown.
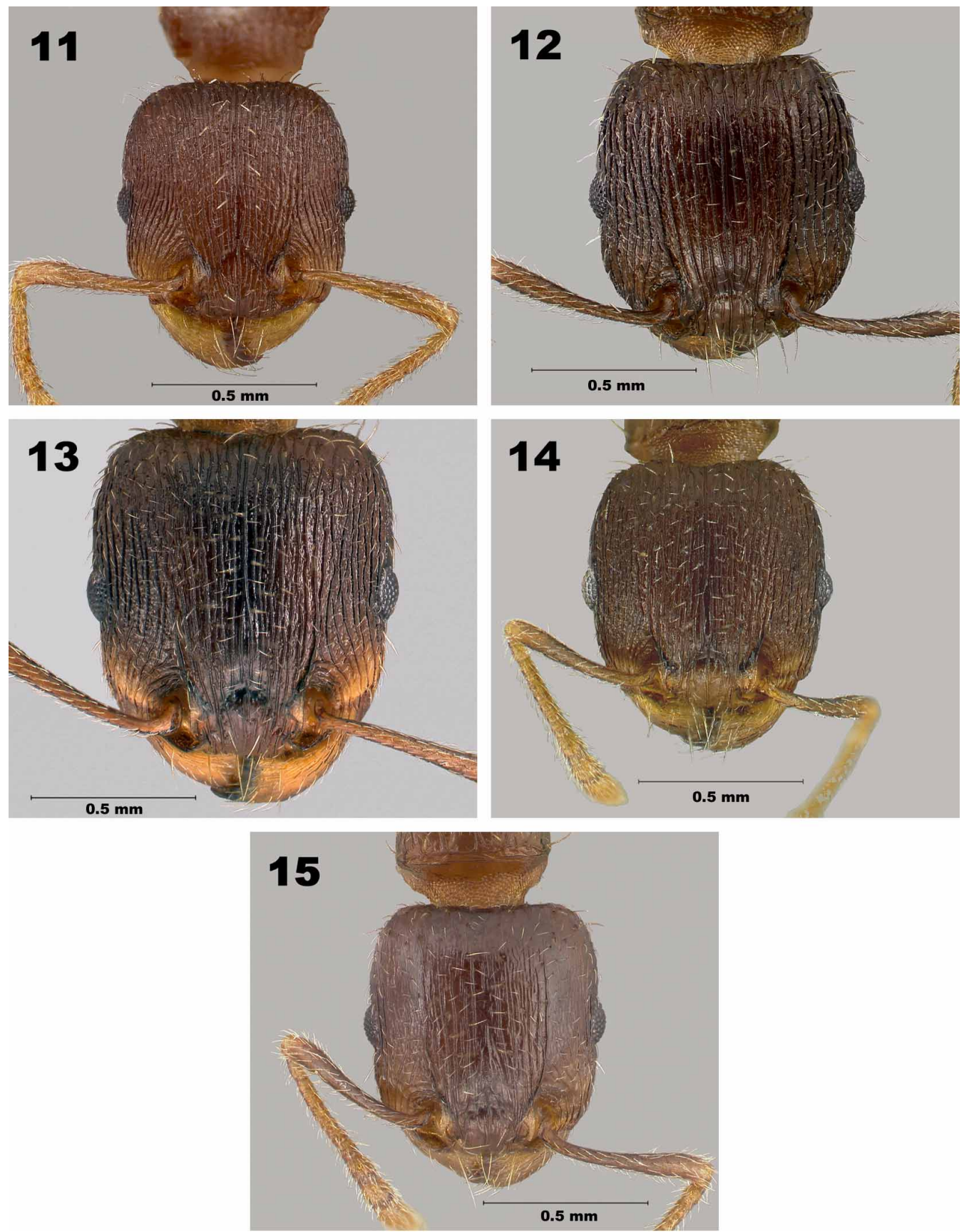

FIGURES 11-15. Tetramorium workers, full-face view of heads. 11, T. forte; 12, T. chefketi; 13, T. moravicum; 14, T. alternans; 15, T. caespitum s.l. See Appendix B for provenance of specimens depicted. 

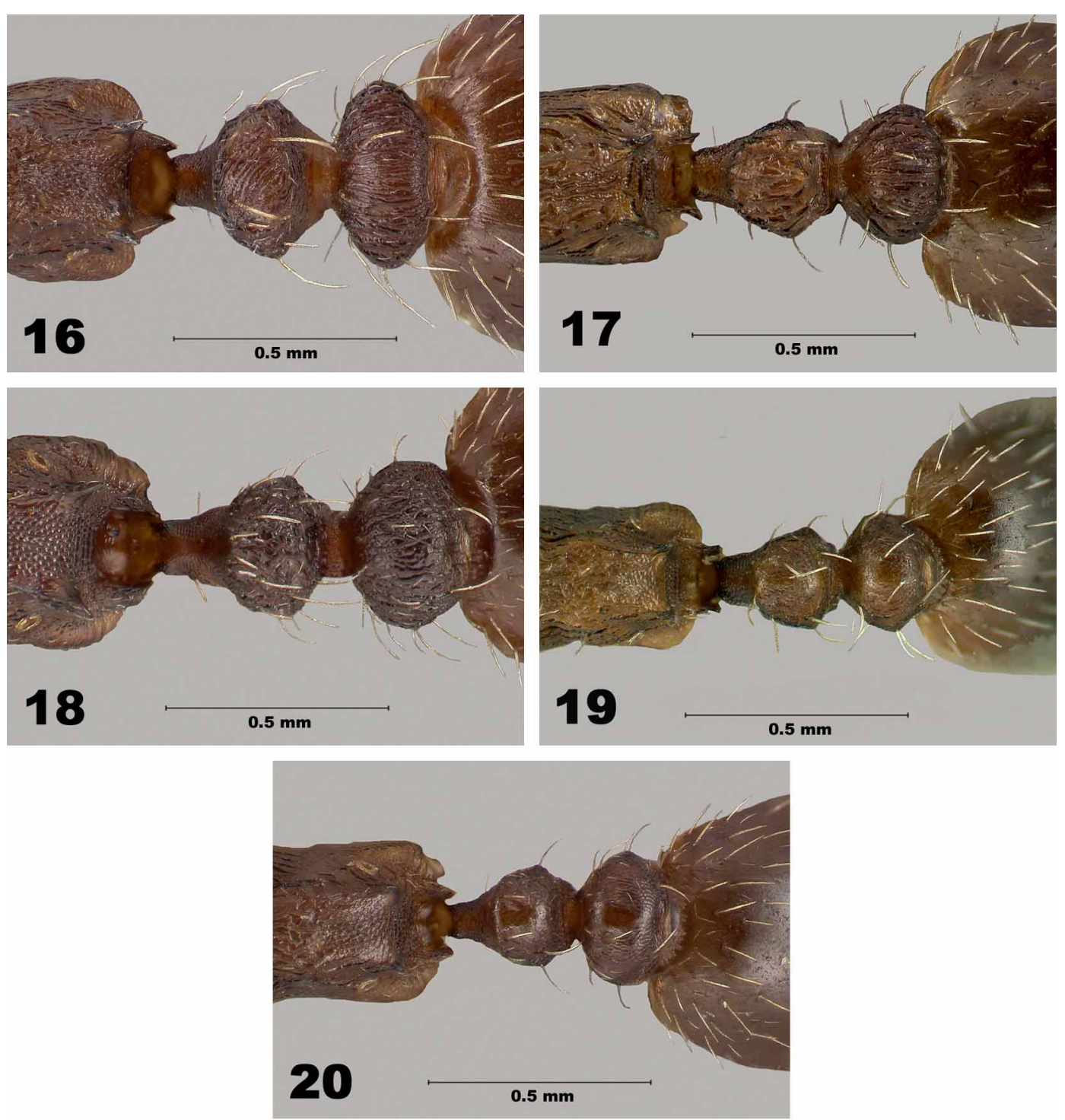

FIGURES 16-20. Tetramorium workers, dorsal views showing petiole and postpetiole. 16, T. forte; 17, T. chefketi; 18, T. moravicum; 19, T. alternans; 20, T. caespitum s.l. See Appendix B for provenance of specimens depicted.

Males of T. caespitum s.l. are much larger (nest means of ML always $>2.500 \mathrm{~mm}$ ) than those of T. forte with narrower waist segments (nest means of WI-A always < 0.240 ), the latter also applies to those of $T$. semilaeve. The male of $T$. meridionale has not been described. 
TABLE 1. Measurements and indices suitable for differentiation of Tetramorium forte workers from the similar species T. chefketi, T. moravicum and T. alternans, as well as from T. caespitum s.l. See Appendix B for provenance of specimens measured.

\begin{tabular}{llll}
\hline worker & ML & SL/HS & MW/ML \\
\hline $\begin{array}{l}\text { T. forte } \\
(\mathrm{n}=34)\end{array}$ & $0.986 \pm 0.111 \mathrm{~mm}$ & $0.786 \pm 0.026$ & $0.560 \pm 0.032$ \\
$\begin{array}{l}\text { T. chefketi } \\
(\mathrm{n}=28)\end{array}$ & $(0.831-1.194)$ & $(0.727-0.840)$ & $(0.509-0.675)$ \\
$\begin{array}{l}\text { T. moravicum } \\
(\mathrm{n}=74)\end{array}$ & & $0.478 \pm 0.021$ \\
$\begin{array}{l}\text { T. alternans } \\
\text { (n=6) }\end{array}$ & & $(0.418-0.527)$ \\
$\begin{array}{l}\text { T. caespitum } \text { s.l. } \\
(\mathrm{n}=18)\end{array}$ & $0.809 \pm 0.038 \mathrm{~mm}$ & $0.699 \pm 0.013$ & \\
\hline
\end{tabular}

continued.

\begin{tabular}{lllll}
\hline worker & PEW/HS & PPL/PPW & WI-A & WI-B \\
\hline T. forte & $0.360 \pm 0.019$ & $0.622 \pm 0.044$ & $0.322 \pm 0.019$ & $0.390 \pm 0.018$ \\
$(\mathrm{n}=34)$ & $(0.311-0.402)$ & $(0.553-0.688)$ & $(0.269-0.359)$ & $(0.338-0.430)$ \\
T. chefketi & $0.316 \pm 0.021$ & $0.767 \pm 0.058$ & $0.257 \pm 0.016$ & \\
$(\mathrm{n}=28)$ & $(0.244-0.357)$ & $(0.611-0.854)$ & $(0.221-0.310)$ & \\
T. moravicum & & $0.766 \pm 0.065$ & $0.267 \pm 0.017$ & \\
$(\mathrm{n}=74)$ & & $(0.632-0.927)$ & $(0.236-0.312)$ & \\
T. alternans & & $0.729 \pm 0.027$ & & $0.352 \pm 0.019$ \\
$(\mathrm{n}=6)$ & & $(0.682-0.750)$ & & $(0.324-0.373)$ \\
T. caespitum s.1. & & & $0.269 \pm 0.017$ & \\
$(\mathrm{n}=18)$ & & & $(0.239-0.295)$ & \\
\hline
\end{tabular}

\section{Distribution and biology}

López (1991) compiled the first comprehensive list of collecting localities of $T$. forte on the Iberian Peninsula (also presented as a distribution map in López Gómez 1988). From these data it is evident that $T$. forte occurs throughout Spain up to the extreme northwest, although the species might be absent from the north coast beyond the Cantabrian Mts. There is no obvious preference for areas with a stronger Mediterranean climatic influence. In the Sierra Nevada, the species occurs at least up to 2200m. Many additional Spanish records (e.g. Tinaut 1991; De Haro \& Collingwood 1991, 1992; Espadaler \& Suñer 1995; Espadaler 1997b; Espadaler \& Roig 2001; Reyes López \& García 2001) confirm the ecologically generalistic occurrence of the species, which also holds true for the distribution pattern in Portugal (Paiva et al. 1990; De Haro \& Collingwood 1992; Tinaut \& 
Ruano 1994; Cammell et al. 1996; Way et al. 1997; Salgueiro 2002b, 2003; present study). Menozzi (1926) and Wheeler (1926) reported T. forte from Mallorca, but its presence on the Balearic Islands should be reconfirmed due to the commonly dubious application of the name.

TABLE 2. Measurements and indices suitable for differentiation of Tetramorium forte gynes from the similar species T. chefketi, T. moravicum and T. alternans, as well as from T. caespitum s.l. See Appendix B for provenance of specimens measured.

\begin{tabular}{llll}
\hline gyne & ML & MW & HS/ML \\
\hline $\begin{array}{l}\text { T. forte } \\
(\mathrm{n}=23)\end{array}$ & $\begin{array}{l}1.762 \pm 0.101 \mathrm{~mm} \\
(1.391-1.879)\end{array}$ & $\begin{array}{l}1.082 \pm 0.074 \mathrm{~mm} \\
(0.830-1.196)\end{array}$ & $\begin{array}{l}0.622 \pm 0.028 \\
\text { T. chefketi } \\
(\mathrm{n}=22)\end{array}$ \\
$\begin{array}{l}\text { T. moravicum } \\
(\mathrm{n}=25)\end{array}$ & $\begin{array}{l}0.581-0.727) \\
\text { T. alternans } \\
(\mathrm{n}=1)\end{array}$ & $(1.830-2.440)$ & \\
$\begin{array}{l}\text { T. caespitum } \text { s.1. } \\
(\mathrm{n}=10)\end{array}$ & & & \\
\hline
\end{tabular}

continued.

\begin{tabular}{|c|c|c|c|c|}
\hline gyne & MW/ML & PEW/HS & PPW/HS & WI-A \\
\hline $\begin{array}{l}\text { T. forte } \\
(\mathrm{n}=23)\end{array}$ & $\begin{array}{l}0.614 \pm 0.019 \\
(0.568-0.653)\end{array}$ & $\begin{array}{l}0.511 \pm 0.037 \\
(0.421-0.569)\end{array}$ & $\begin{array}{l}0.650 \pm 0.045 \\
(0.525-0.712)\end{array}$ & $\begin{array}{l}0.360 \pm 0.017 \\
(0.324-0.392)\end{array}$ \\
\hline $\begin{array}{l}\text { T. chefketi } \\
(\mathrm{n}=22)\end{array}$ & $\begin{array}{l}0.586 \pm 0.029 \\
(0.546-0.635)\end{array}$ & $\begin{array}{l}0.395 \pm 0.018 \\
(0.365-0.433)\end{array}$ & $\begin{array}{l}0.502 \pm 0.028 \\
(0.457-0.564)\end{array}$ & $\begin{array}{l}0.268 \pm 0.012 \\
(0.250-0.291)\end{array}$ \\
\hline $\begin{array}{l}\text { T. moravicum } \\
(\mathrm{n}=25)\end{array}$ & & $\begin{array}{l}0.405 \pm 0.018 \\
(0.361-0.436)\end{array}$ & & $\begin{array}{l}0.257 \pm 0.015 \\
(0.213-0.291)\end{array}$ \\
\hline $\begin{array}{l}\text { T. alternans } \\
(\mathrm{n}=1)\end{array}$ & 0.564 & 0.418 & 0.526 & 0.292 \\
\hline $\begin{array}{l}\text { T. caespitum s.l. } \\
(\mathrm{n}=10)\end{array}$ & & & & $\begin{array}{l}0.258 \pm 0.020 \\
(0.228-0.293)\end{array}$ \\
\hline
\end{tabular}

Abundant samples compiled from Morocco (Cagniant 1997, collecting localities not specified) show $T$. forte to occur in diverse habitats from sea-level up to $2000 \mathrm{~m}$ in the north of the country (especially in the Middle Atlas), much as in southern Spain (Fig. 21). In the south, however, it appears much more localized at higher elevations of the High Atlas. According to Csősz (in litt.), a few samples from Algeria have been traced in collections. Three workers from Ponta Delgada (São Miguel, Azores, leg. W.M. Wheeler) in NHMB had previously been determined as T. forte, but proved to belong to T. caespitum s.l. upon investigation. The ant fauna of the Azores, largely or entirely introduced, is well 


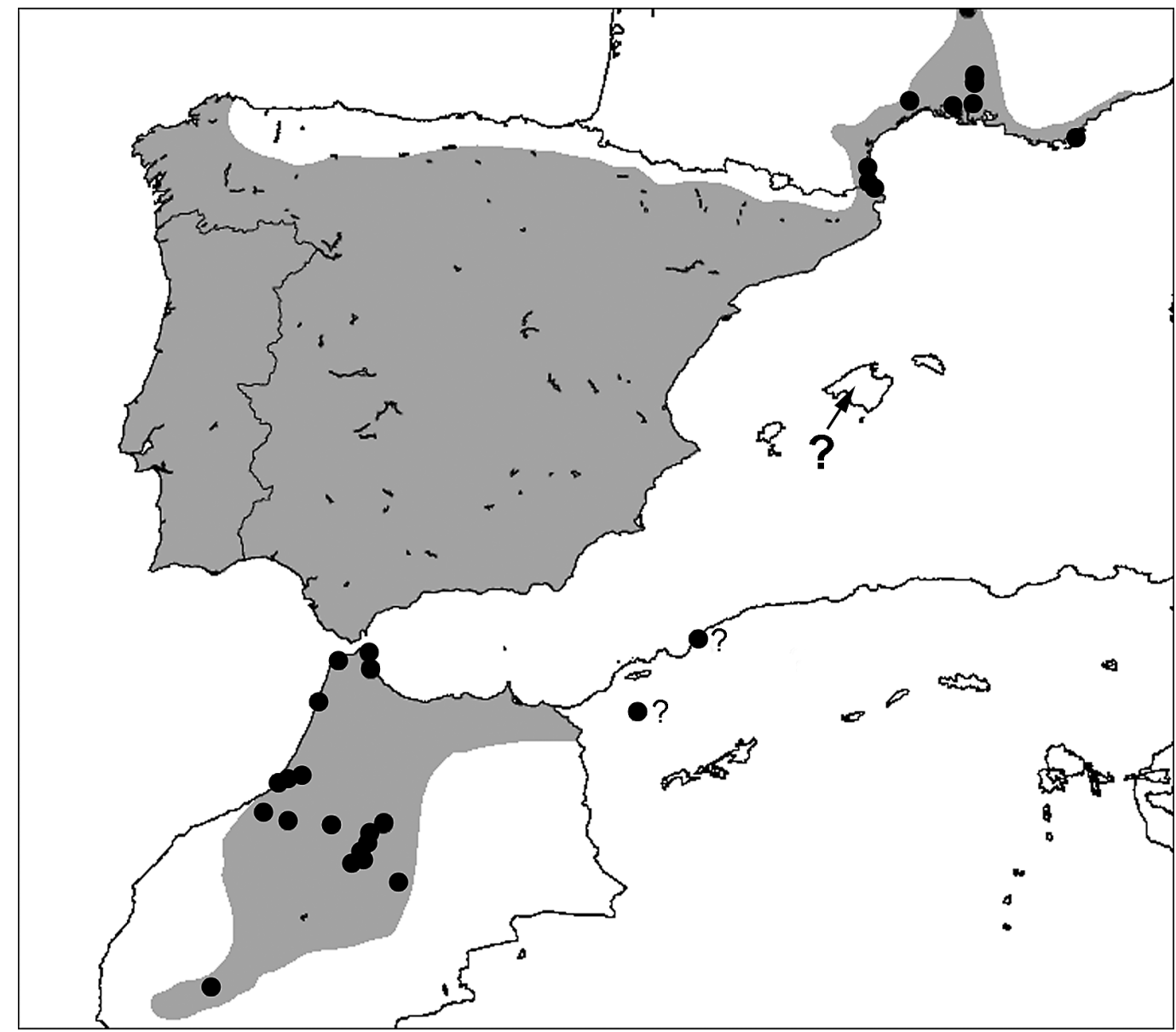

FIGURE 21. Overview of the distribution of Tetramorium forte Forel, 1904. Available records are indicated separately only for France and Morocco, as they are very numerous for Spain and Portugal. The occurrence on the Baleares needs corroboration. The only known Algerian record most likely refers to one of the two localities indicated.

The range of $T$. forte extends into France along the Mediterranean coast, but except for one sample in the extreme southeast (Sommer \& Cagniant 1988), no reliable records other than the original description had been published prior to this study. As Bernard's (1967) understanding of $T$. forte was evidently insufficient, his locality citings from the Îles d'Hyères and the Côte d'Azur need to be re-investigated. Consequently, a gyne from Cavalaire-sur-Mer (Var) in NHMB currently represents the easternmost confirmed record. The northernmost locality in the Dept. Loire indicates an inland extension along the Rhône river for more than 200km. Only recent investigations (Schulz 1996; Schlick-Steiner et al., 
in press; Güsten, unpubl.) have shown that the distribution of T. forte in southern France is entwined with that of T. moravicum, which is very similar in the worker morph. Current data suggest that $T$. moravicum occurs at xerothermic localities with less overt Mediterranean influence compared with those of $T$. forte (Fig. 22). Tetramorium moravicum is usually found above $600 \mathrm{~m}$ where its range approaches the coast, although it may inhabit lower elevations in the Dept. Alpes-Maritimes where the ocurrence of $T$. forte is not confirmed. The overall distribution pattern of $T$. forte (Fig. 21) renders likely the postglacial recolonization into its present range from an atlanto-mediterranean refuge. Resulting contact with the ecologically similar $T$. moravicum progressing from a pontomediterranean refuge (Schlick-Steiner et al., in press) might have impeded further spreading of both species, but this needs additional investigation.

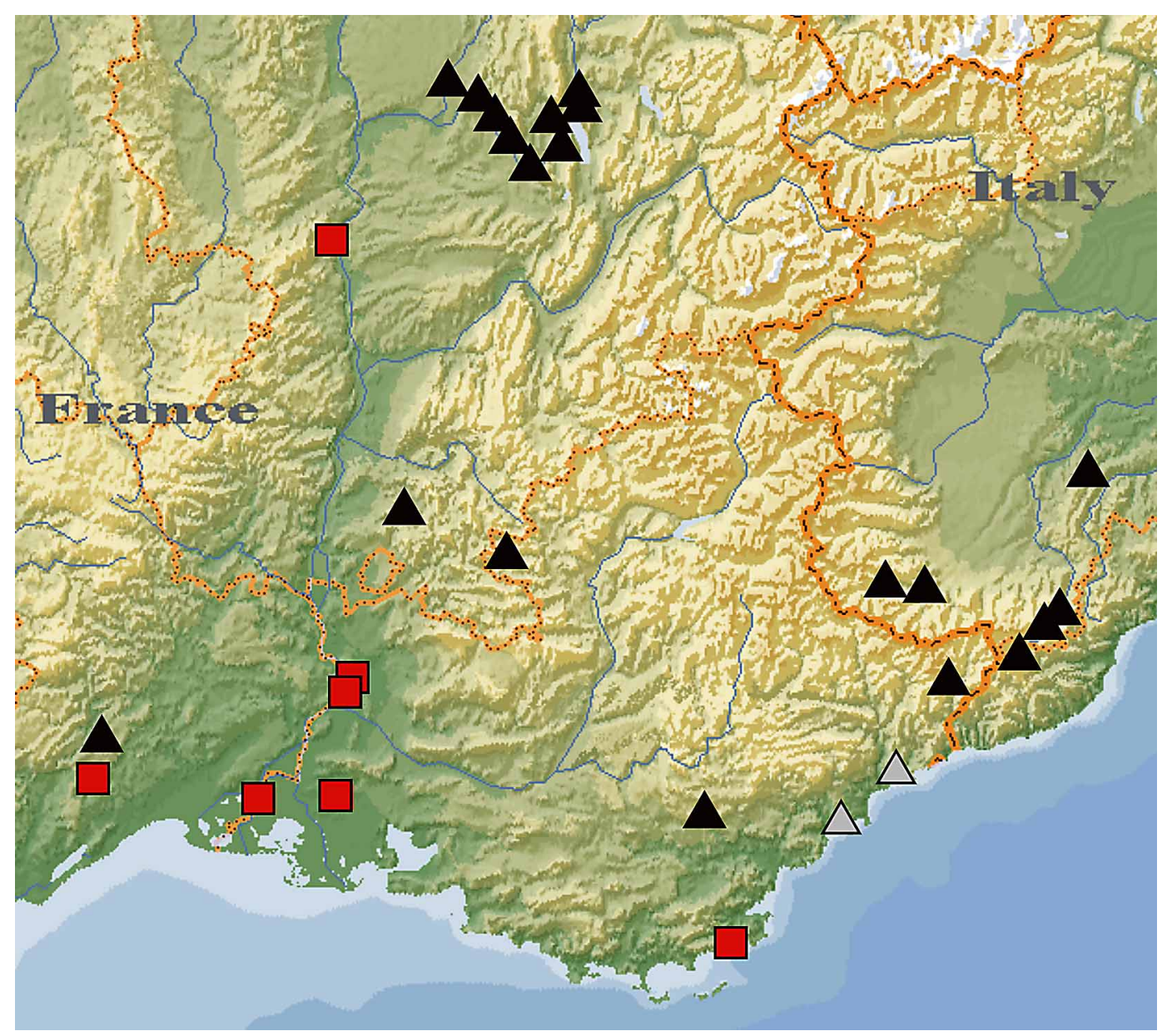

FIGURE 22. Distribution of Tetramorium forte Forel, 1904 (squares) and Tetramorium moravicum Kratochvil, 1941 (black triangles) in southeastern France and adjacent Italy. Records of $T$. moravicum are largely unpublished; the localities given on old museum specimens as "Nice" and "Cannes" may be imprecise (grey triangles). 
As stated above, records of $T$. forte from Corsica (Casevitz-Weulersse 1974, 1990a, 1990b) were based on a different concept of the species. Our study of comprehensive samples from Corsica and Sardinia indicated that the true $T$. forte is not present on the Tyrrhenian Islands.

Apparent polygynous colonies have been observed in $T$. forte several times throughout its range (e.g. near Avignon, France; near Ifrane, Morocco), and the functional status as queens has been confirmed by dissection in one instance (five inseminated egg-laying queens: Sierra Nevada, Spain). Winged sexuals were recorded in T. forte colonies during late May in Spain, but during late June in the mountains of northern Portugal. The lepismatid silver-fish Proatelurina pseudolepisma (Grassi, 1887) is a generalistic myrmecophile commonly found inhabiting nests of $T$. forte (Molero-Baltanás et al. 1998). Astenus (Eurysunius) alcarazae Assing, 2003 and probably other species of the subgenus also occur with T. forte; these are myrmecophilous staphylinid beetles specialized to live in the colonies of ants of the genus Tetramorium in the western Palaearctic (Assing 2003). However, no records of ant social parasites collected together with $T$. forte are available, including the inquilines Strongylognathus testaceus (Schenck, 1852) and Anergates atratulus (Schenck, 1852), which are known to use a relatively broad range of hosts in the genus Tetramorium (e.g. Sanetra et al. 1999; Sanetra \& Buschinger 2000). Polygyny in a potential host species might be seen as a critical barrier for colony-founding queens of socially parasitic ants (see also Sanetra \& Güsten 2001).

\section{Appendix A: Taxonomic notes on Tetramorium species discussed in this paper}

\section{Tetramorium chefketi Forel, 1911}

Tetramorium caespitum var. chefketi Forel, 1911

Tetramorium chefketi Forel: Agosti \& Collingwood 1987a, 1987b

According to Agosti and Collingwood (1987a), the species (misspelled "chefteki"), which was described from the European part of Turkey, occurs also in Greece and Anatolia. We compared specimens from these areas with the worker syntypes (MHNG) and support this view. Schulz (1996) presented characters differentiating T. chefketi from the closely similar T. moravicum and T. forte, and Sanetra and Buschinger (2000) as well as SchlickSteiner et al. (2005) studied its phylogenetic position in relation to T. forte, T. moravicum and T. semilaeve. Csösz et al. (unpubl.) ascribe the paralectotypes of T. forte from Alušta (Crimea, Ukraine) to T. caespitum sarkissiani Forel, 1911 and regard that taxon as synonymous to $T$. chefketi, which has equal priority. 
Tetramorium caespitum v. alternans Santschi, 1929

Cagniant (1997), treating this taxon as a subspecies of T. caespitum, cites records from diverse sites throughout Morocco. We have recently procured further samples, including the first known gyne (Morocco, Middle Atlas, Reg. Meknès, in CAS), and regard it as a good species which may occur throughout the Maghreb. Some specimens from Tunisia (in NHMB) are very similar, as are workers from the northeastern mountains of Teneriffa.

\section{Tetramorium maurum Santschi, 1918}

Tetramorium caespitum st. maura Santschi, 1918

Tetramorium maurum Santschi: Santschi 1929

The taxonomy of this species is unsettled: the type series contains syntypes from all three Maghreb countries and is probably heterogeneous. However, the principal collection series among the syntypes in NHMB, comprising gynes, originate from northern Tunisia. We base the comparison with $T$. forte on these gynes. There is currently no indication that the species occurs in Morocco.

\section{"Tetramorium caespitum sensu lato"}

Species morphologically similar to $T$. caespitum (Linnaeus, 1758) are the dominant Tetramorium ants in temperate parts of Eurasia. Cammaerts et al. (1985) distinguished $T$. impurum (Förster, 1850) from T. caespitum in central Europe based on male genitalic characters. It has recently become clear that the T. caespitum/impurum species complex constitutes in fact an assembly of cryptic species, which cannot yet be delimited clearly or assigned valid names (Steiner et al. 2002; Schlick-Steiner et al., 2006). More than one species is included within the current concepts of both T. caespitum and T. impurum. Throughout this paper we use the term " $T$. caespitum s.l." to denote species of the complex.

\section{Appendix B: Provenance of specimens figured and measured}

\section{Specimens depicted in Figs 3-20}

Tetramorium forte

worker (Figs 11, 16), male (Figs 4, 6): Portugal, Distr. Bragança, Montesinho gyne (Figs 3, 5): Portugal, Distr. Viseu, Serra de Montemuro 
worker (Figs 12, 17): Turkey, Prov. Konya, 20 km sw Ayrancı

gyne (Fig. 7): Turkey, Prov. Artvin, ca. 30 km s Artvin

\section{Tetramorium moravicum}

worker (Figs 13, 18): France, Dept. Savoie, Serrières-en-Chautagne

gyne (Fig. 8): France, Dept. Drôme, Col du Pertuis

\section{Tetramorium alternans}

worker (Figs 14, 19): Morocco, Reg. Meknès, ca. 40 km s Aïn Leuh

\section{Tetramorium caespitum s.l.}

worker (Figs 15, 20): Spain, Prov. Huesca, Puerto de Monrepós

gyne (Fig. 9): Spain, Prov. Ávila, 5 km sw El Tiemblo

\section{Tetramorium meridionale}

gyne (Fig. 10): Italy, Sardegna, Prov. Sassari, Lago di Coghinas

\section{Specimens measured for Tables 1 and 2}

\section{Tetramorium forte}

France, Dept. Vaucluse, 7 km n Avignon; Spain, Prov. Cuenca, 2 km e Villalba de la Sierra; Spain, Prov. Jaén, Puerto de los Jardines; Spain, Prov. Granada, Sierra Nevada (2200m); Spain, Prov. Badajoz, Embalse de Orellana; Portugal, Distr. Viseu, Caldas da Felgueira; Portugal, Distr. Castelo Branco, nr. Monsanto; Morocco, Reg. Kénitra, Forêt de la Mamora; Morocco, Reg. Meknès, Aguelmame Azigza

\section{Tetramorium chefketi}

Turkey, Prov. Sinop, 5 km e Kabali; Turkey, Prov. Kastamonu, 30 km s Inebolu; Turkey, Prov. Niğde, 10 km nw Acipinar; Turkey, Prov. Konya, Ereğli swamps; Turkey, Prov. Konya, Belören; Greece, Pref. Arcadia, 5 km sw Levidion; Greece, Pref. Pieria, 4 km w Litóhoro

\section{Tetramorium moravicum}

Turkey, Prov. Kars, nr. Posof; Turkey, Prov. Van, 8 km e Budakli; Slovakia, Reg. Nitriansky Kraj, Kozarovce; Czech Republic, Reg. Vysočina, Mohelno; Austria, State Niederösterreich, St. Pölten; Germany, State Baden-Württemberg, Vogtsburg; Germany, State Rheinland-Pfalz, Lorchhausen; France, Dept. Alpes-Maritimes, Maurioun; France, Dept. Savoie, 12 km e Belley; France, Dept. Savoie, Serrières-en-Chautagne 
Morocco, Reg. Meknès, ca. 40 km s Aïn Leuh

Tetramorium caespitum s.l.

Greece, Pref. Corinthia, Killini N-slope; Germany, State Rheinland-Pfalz, Lorchhausen; France, Dept. Gard, 15 km nnw Le Vigan; Spain, Prov. Girona, 5 km sse Camprodon; Spain, Prov. Granada, Puerto de la Ragua

\section{Appendix C: Taxa excluded from the genus Tetramorium}

\section{Myrmica specioides Bondroit, 1918}

Myrmica specioides Bondroit, 1918

Tetramorium silvestrianum Emery, 1924: syn. nov.

Myrmica rugulosoides var. striata Finzi, 1926 (synonymy: Collingwood 1979)

Myrmica scabrinodis var. ahngeri Karavaiev, 1926 (synonymy: Seifert 1988)

Myrmica puerilis Stärcke, 1942 (synonymy: Collingwood \& Yarrow 1969)

Myrmica neglecta Stärcke, 1942 (nomen nudum)

Myrmica scabrinodis var. atlantica Stärcke, 1942 (nomen nudum)

Myrmica (Myrmica) balcanica Sadil, 1952 (synonymy: Pisarski 1975)

Myrmica (Myrmica) balcanica var. scabrinodoides Sadil, 1952 (synonymy: Pisarski 1975)

\section{Material examined}

1 ६, lectotype of $\boldsymbol{T}$. silvestrianum Emery (hereby designated): „Manresa Silvestri / Typus / Tetramorium silvestrianum Emery Typus / Myrmica nec Tetramorium $\mathrm{M}^{\mathrm{F}}[1$ abel most likely by B. Poldi] / Lectotypus Tetramorium silvestrianum Emery des. R. Güsten, A. Schulz \& M. Sanetra 2005“ (MCSN); 1 ఛ, „Solden (A.), 9.VII.20 / Tetramorium silvestrianum Em. var.!, Santschi det. 1926 / Sammlung Dr. F. Santschi, Kairouan (NHMB)“.

One of the two original syntypes of T. silvestrianum Emery remains at MCSN. It is in good condition and can easily be determined as a worker of Myrmica specioides Bondroit. Also, Emery's (1924) description matches this specimen and his outline figure shows the petiole shape of $M$. specioides, so that there is no reason to believe that the other syntype represented a different species. Nevertheless, the surviving specimen is designated as lectotype in order to firmly establish the synonymy. We cannot explain Emery's (1924) gaffe. Continuing the misconception, F. Santschi also determined a worker of $M$. specioides from "Solden (A.)" (probably Sölden, Tirol, Austria) in his collection as T. silvestrianum. Collingwood and Yarrow (1969), Collingwood (1978) and López (1991) regarded $T$. silvestrianum as a synonym of $T$. forte on the grounds that the descriptions where allegedly corresponding. A worker ant from Genève (Switzerland) was determined 
as T. silvestrianum by Collingwood (in López 1991).

The synonymy of M. specioides Bondroit is summarized above. Seifert (2002) has demonstrated that M. specioides is not a synonym of M. bessarabica Nassonov, 1889 as previously stated by Atanassov and Dlussky (1992). We have not included several junior synonyms proposed by Dlussky et al. (1990) and Arakelian (1994) concerning taxa described from areas east of the range of $M$. specioides as given by Seifert (1988), chiefly from the Caucasus. These synonymies need reinvestigation.

\section{Acknowledgements}

We wish to express our gratitude to the Staatliches Museum für Naturkunde, Karlsruhe, and specifically Christiana Klingenberg and Manfred Verhaagh, for providing the photographic equipment and for their gracious and very helpful advice. Many Thanks also to Birgit Schlick-Steiner and Florian Steiner (Vienna) who shared all unpublished information from their ongoing project on Palaearctic Tetramorium, considerably improving the background for our study. Sándor Csősz (Budapest) also kindly communicated results from his current revisionary work. The following people hosted us during research visits to public collections or sent important specimens and valuable information: Bernhard Merz (Genève), Daniel Burckhardt and Michel Brancucci (Basel), Manfred Koch (Berlin), Valter Raineri and Roberto Poggi (Genova), Piero Baronio (Bologna), and Mariana Pascu (Sibiu). Many colleagues graciously donated collected ants to CAS, among them our field companions Ralf Schumann, Tom Aßmuth (Darmstadt) and Katrin Vock (Leverkusen). Figure 21 was prepared partly using DMAP for Windows by Alan Morton (Windsor). Some parts of this study were supported by a grant from the Deutsche Forschungsgemeinschaft (Bu 310/26-1) to Alfred Buschinger (Darmstadt) who is thanked for his participation in the project.

\section{References}

Acosta Salmerón, F.J., Martinez Ibáñez, M.D. \& Morales, M. (1983) Contribución al conocimiento de la mirmecofauna del encinar peninsular (1). (Hym. Formicidae). Boletín de la Asociación Española de Entomologia, 6, 379-391.

Agosti, D. \& Collingwood, C.A. (1987a) A provisional list of the Balkan ants (Hym., Formicidae) and a key to the worker caste. I. Synonymic list. Mitteilungen der Schweizerischen Entomologischen Gesellschaft, 60, 51-62.

Agosti, D. \& Collingwood, C.A. (1987b) A provisional list of the Balkan ants (Hym. Formicidae) with a key to the worker caste. II. Key to the worker caste, including the European species without the Iberian. Mitteilungen der Schweizerischen Entomologischen Gesellschaft, 60, 261-293.

Arakelian, G.R. (1994) Fauna of the Republic of Armenia. Hymenopterous insects. Ants (Formicidae) [in Russ.], Gitutyun NAN PA, Erevan, 153 pp. 
Arnol'di, K.V. (1968) Important additions to the myrmecofauna (Hymenoptera, Formicidae) of the USSR and descriptions of new forms [in Russ.]. Zoologiceskij Zhurnal, 47, 1800-1822.

Assing, V. (2003) New species and records of Eurysunius, subgenus of Astenus Dejean, from the Iberian Peninsula (Coleoptera: Staphylinidae, Paederinae). Linzer biologische Beiträge, 35, 693-700.

Atanassov, N. \& Dlussky, G.M. (1992) Fauna of Bulgaria. Hymenoptera, Formicidae (Fauna Bulgarica, 22) [in Bulg.], Academia Scientiarum Bulgarica, Sofia, 310 pp.

Bernard, F. (1967) Les Fourmis (Hymenoptera Formicidae) d'Europe Occidentale et Septentrionale (Faune de 1’Europe et du Bassin Méditerranéen, 3.), Masson et $C^{\text {ie }}$, Paris, 411 pp.

Bolton, B. (1976) The ant tribe Tetramoriini (Hymenoptera: Formicidae). Constituent genera, review of smaller genera and revision of Triglyphothrix Forel. Bulletin of the British Museum (Natural History), Entomology, 34, 281-379.

Bolton, B. (1977) The ant tribe Tetramoriini (Hymenoptera: Formicidae). The genus Tetramorium Mayr in the Oriental and Indo-Australian regions, and in Australia. Bulletin of the British Museum (Natural History), Entomology, 36, 67-151.

Bolton, B. (1979) The ant tribe Tetramoriini (Hymenoptera: Formicidae). The genus Tetramorium Mayr in the Malagasy region and in the New World. Bulletin of the British Museum (Natural History), Entomology, 38, 129-181.

Bolton, B. (1980) The ant tribe Tetramoriini (Hymenoptera: Formicidae). The genus Tetramorium Mayr in the Ethiopian zoogeographical region. Bulletin of the British Museum (Natural History), Entomology, 40, 193-384.

Bolton, B. (1995) A New General Catalogue of the Ants of the World, Harvard University Press, Cambridge (Mass.), 504 pp.

Bondroit, J. (1918) Les fourmis de France et de Belgique. Annales de la Société Entomologique de France, 87, 1-174.

Bondroit, J. (1920) Notes diverses sur des fourmis d'Europe. Annales de la Société Entomologique de Belgique, 59[1919], 143-158.

Cagniant, H. (1964) Etude de quelques fourmis marocaines. Statistique provisoire des Formicidae du Maroc. Bulletin de la Société d'Histoire Naturelle de l'Afrique du Nord, 53[1962], 83-118.

Cagniant, H. (1997) Le genre Tetramorium au Maroc (Hymenoptera: Formicidae): clé et catalogue des espèces. Annales de la Société Entomologique de France (N.S.), 33, 89-100.

Cammaerts, R., Pasteels, J.M. \& Roisin, Y. (1985) Identification et distribution de Tetramorium caespitum (L.) et T. impurum (Foerster) en Belgique (Hymenoptera Formicidae). Actes des Colloques Insectes Sociaux, 2, 109-118.

Cammell, M.E., Way, M.J. \& Paiva, M.R. (1996) Diversity and structure of ant communities associated with oak, pine, eucalyptus and arable habitats in Portugal. Insectes Sociaux, 43, 37-46.

Casevitz-Weulersse, J. (1974) Fourmis récoltées en Corse et en Sardaigne. Annales de la Société Entomologique de France (N.S.), 10, 611-621.

Casevitz-Weulersse, J. (1990a) Étude systématique de la myrmécofaune corse (Hymenoptera, Formicidae) (Deuxième partie). Bulletin du Muséum National d'Histoire Naturelle (Section A: Zoologie, Biologie et Écologie Animales), (4)12, 415-442.

Casevitz-Weulersse, J. (1990b) Étude des peuplements de fourmis de la Corse (Hymenoptera, Formicidae). Revue d'Écologie et de Biologie du Sol, 27, 29-59.

Collingwood, C.A. (1978) A provisional list of Iberian Formicidae with a key to the worker caste (Hym. Aculeata). Eos, 52, 65-95.

Collingwood, C.A. (1979) The Formicidae (Hymenoptera) of Fennoscandia and Denmark. Fauna Entomologica Scandinavica, 8, 1-174.

Collingwood, C.A. \& Yarrow, I.H.H. (1969) A survey of Iberian Formicidae (Hymenoptera). Eos, 44, 53-101.

De Haro, A. \& Collingwood, C.A. (1988) Prospección mirmecológica por las sierras de Aitana- 
Alfaro y los cabos de la Nao-San Antonio (Alicante) y su comparación con la fauna balear y de Córcega-Cerdeña. Orsis, 3, 165-172.

De Haro, A. \& Collingwood, C.A. (1991) Prospección mirmecológica en la Cordillera Ibérica. Orsis, 6, 109-126.

De Haro, A. \& Collingwood, C.A. (1992) Prospección mirmecológica por Extremadura (España) y Sao Brás-Almodovar, Alcácer do Sal, Serra da Estrela (Portugal). Boletim da Sociedade Portuguesa de Entomologia, Supl. 3(1), 95-104.

De Haro, A. \& Collingwood, C.A. (1994) Prospección mirmecológica por el litoral mediterráneo de Marruecos (Cabo Negro, Martil, Oued Lau) y su comparación con la zona meridional ibérica. Orsis, 9, 97-104.

De Haro, A. \& Collingwood, C.A. (1997) Prospección mirmecológica por la península Tingitana al norte del Rif (Marruecos). Orsis, 12, 93-99.

Dlussky, G.M., Soyunov, O.S. \& Zabelin, S.I. (1990) The Ants of Turkmenia [in Russ.], Ylym Press, Ashkhabad, 273 pp.

Emery, C. (1909) Beiträge zur Monographie der Formiciden des paläarktischen Faunengebietes. (Hym.). Teil IX. Deutsche Entomologische Zeitschrift, 1909, 695-712.

Emery, C. (1924) Formiche di Spagna raccolte dal Prof. Filippo Silvestri. Bollettino del Laboratorio di Zoologia Generale e Agraria della R. Scuola Superiore d'Agricoltura in Portici, 17[1923], 164-171.

Espadaler, X. (1997a) Formicidos de las Sierras de Cazorla, del Pozo y Segura (Jaen, España) (Hymenoptera, Formicidae). Ecología (Madrid), 11, 489-499.

Espadaler, X. (1997b) Catàleg de les Formigues (Hymenoptera: Formicidae) dels Països Catalans. In: Bellavista, J. (Ed) IX Sessió Conjunta d'Entomologia ICHN - SCL, 1995, Societat Catalana de Lepidopterologia, Barcelona, 23-42.

Espadaler, X. \& Roig, X. (2001) Ants from the Montnegre-Corredor Natural Park (NE Spain) with description of the male Lasius cinereus Seifert (Hymenoptera, Formicidae). Miscellània Zoològica, 23(2)[2000], 45-53.

Espadaler, X. \& Suñer, D. (1995) Per què hi ha formigues del Montgrí (Girona) que no es troben a l'illa Meda Gran. Orsis, 10, 91-97.

Finzi, B. (1926) Le forme europee del genere Myrmica Latr. Primo contributo. Bollettino della Società Adriatica di Scienze Naturali, 29, 71-119.

Forel, A. (1904a) Note sur les fourmis du Musée Zoologique de l’Académie Impériale des Sciences à St. Pétersbourg. Ezegodnik Zoologiceskago Muzeja Imperatorskoj Akademii Nauk, 8[1903], 368-388.

Forel, A. (1904b) Miscellanea myrmécologiques. Revue Suisse de Zoologie, 12, 1-52.

Forel, A. (1905) Miscellanea myrmécologiques II (1905). Annales de la Société Entomologique de Belgique, 49, 155-185.

Forel, A. (1911) Fourmis nouvelles ou intéressantes. Bulletin de la Société Vaudoise des Sciences Naturelles, 47, 331-400.

Heinze, J. (1986) A new find of Paratrechina longicornis (Latreille 1802) on the Azores (Hymenoptera, Formicidae). Bocagiana, 101, 1-3.

Karavaiev, V. (1926) Myrmecological fragments [in Ukr.]. Trudy Ukrains'ka Akademiya Nauk, Fizichno-Matematichnoho Viddilu, 4, 65-69.

López Gómez, F. (1988) Aproximacion al Estudio del Genero Tetramorium Mayr, 1855 en la Peninsula Iberica (Hymenoptera, Formicidae), Facultad de Ciencias Biologicas de la Universidad Complutense, Madrid, 245 pp. (unpublished thesis).

López, F. (1991) Estudio morfológico y taxonómico de los grupos de especies ibéricas del género Tetramorium Mayr, 1855 (Hym., Formicidae). Boletín de la Asociación Española de Entomologia, 15, 29-52.

Lorite, P., Carrillo, J.A., Garcia, M.F. \& Palomeque, T. (2000) Chromosome numbers in Spanish 
Formicidae. III. Subfamily Myrmicinae (Hymenoptera). Sociobiology, 36, 555-570.

Markó, B. \& Csősz, S. (2002) Die europäischen Ameisenarten (Hymenoptera: Formicidae) des Hermannstädter (Sibiu, Rumänien) Naturkundemuseums I.: Unterfamilien Ponerinae, Myrmicinae und Dolichoderinae. Annales Historico-Naturales Musei Nationalis Hungarici, 94, 109-121.

Menozzi, C. (1926) Zur Kenntnis der Ameisenfauna der Balearen. Zoologischer Anzeiger, 66, 180-182.

Molero-Baltanás, R., Gaju-Ricart, M., Bach de Roca, C. \& Mendes, L.F. (1998) Description of Atelura valenciana $\mathrm{n}$. sp. (Insecta, Zygentoma) and distribution and myrmecophilic relationships of Proatelurina pseudolepisma in the Iberian peninsula. Miscellània Zoològica, 21, 101-117.

Novak, V. \& Sadil, J. (1941) Klíč k určování mravenců střední Evropy se zvlástním zretelem k mravencí zvírene Cech a Moravy. Entomologicke Listy, 4, 65-115.

Ortiz, F.J. \& Tinaut, J.A. (1988) Formícidos del litoral granadino. Orsis, 3, 145-163.

Paiva, M.R., Way, M.J. \& Cammel, M. (1990) Estudo preliminar sobre a distribuição das formigas nos sistemas florestais em Portugal. Boletim da Sociedade Portuguesa de Entomologia, (4) 17 [=119], 197-207.

Palomeque, T., Chica, E., Cano, M.A., Díaz de la Guardia, R. \& Tinaut, A. (1989) Cytogenetic studies in the genera Pheidole and Tetramorium (Hymenoptera, Formicidae, Myrmicinae). Caryologia, 41[1987], 289-298.

Pisarski, B. (1975) Mrówki, Formicoidea (Katalog fauny Polski, 26), Wydawnictwo Naukowe PWN, Warszawa, 84 pp.

Rabaglia, R.J. (2005) The validity of Xyleborus impressus Eichhoff (Coleoptera: Curculionidae: Scolytinae) as distinct from Xyleborus ferrugineus (Fabricius). The Coleopterists' Bulletin, 59, 261-266.

Radchenko, A.G. (1992) Ants of the genus Tetramorium (Hymenoptera, Formicidae) of the fauna of the USSR. Report 2. [in Russ.]. Zoologiceskij Zhurnal, 71(8), 50-58.

Radchenko, A.G., Czechowski, W. \& Czechowska, W. (1998) The genus Tetramorium Mayr (Hymenoptera, Formicidae) in Poland-a survey of species and a key for their identification. Annales Zoologici (Warszawa), 48, 107-118.

Reyes López, J.L. \& García, G.L. (2001) Nuevos datos sobre el género Cardiocondyla (Hym., Formicidae) en Andalucía (en el Sur de la Península Ibérica). Boletín de la Asociación Española de Entomologia, 25, 125-126.

Röszler, P. (1936) Beiträge zur Kenntnis der Ameisenfauna von Mitteleuropa. III. Teil der Arbeit: „Ein Versuch der systematischen Einteilung der mitteleuropäischen Tetramorium“. Tijdschrift voor Entomologie, 79, 55-63.

Röszler, P. (1937) Beiträge zur Kenntnis der Ameisenfauna von Spanien und anderer mitteleuropäischer Länder. II. Teil der Arbeit: ,Ein Versuch der systematischen Einteilung der mitteleuropäischen Tetramorium“. Verhandlungen und Mitteilungen des Siebenbürgischen Vereins für Naturwissenschaften zu Hermannstadt, 85-86[1935/36], 195-208.

Röszler, P. (1951) Myrmecologisches aus dem Jahre 1938. Zoologischer Anzeiger, 146, 88-96.

Sadil, J.V. (1952) A revision of the Czechoslovak forms of the genus Myrmica Latr. Sborník Entomologického Oddelení Národního Musea v Praze, 27[1951], 233-278.

Salgueiro, J. (2002a) Catálogo dos Formicídeos de Portugal Continental e Ilhas. Boletín de la Sociedad Entomológica Aragonesa, 31, 145-171.

Salgueiro, J. (2002b) Variação anual em três comunidades de formicídeos da Serra da Estrela. Adição de um género novo e de duas espécies novas para Portugal. Boletín de la Asociación Española de Entomologia, 26, 121-131.

Salgueiro, J. (2003) Primeiros registros de formicídeos para duas áreas protegidas portuguesas. Adição de duas novas espécies à mirmecofauna de Portugal. Boletín de la Sociedad Entomológica Aragonesa, 32, 109-110.

Sanetra, M. \& Buschinger, A. (2000) Phylogenetic relationships among social parasites and their 
hosts in the ant tribe Tetramoriini (Hymenoptera: Formicidae). European Journal of Entomology, 97, 95-117.

Sanetra, M. \& Güsten, R. (2001) The socially parasitic ant genus Strongylognathus Mayr in North Africa (Insecta: Hymenoptera: Formicidae). Zootaxa, 20, 1-20.

Sanetra, M., Heinze, J. \& Buschinger, A. (1994) Enzyme polymorphism in the ant genus Tetramorium Mayr and its social parasites (Hymenoptera: Formicidae). Biochemical Systematics and Ecology, 22, 753-759.

Sanetra, M., Güsten, R. \& Schulz, A. (1999) On the taxonomy and distribution of Italian Tetramorium species and their social parasites (Hymenoptera Formicidae). Memorie della Società Entomologica Italiana, 77, 317-357.

Santschi, F. (1918) Nouveaux Tetramorium africains (suite et fin). Bulletin de la Société d'Histoire Naturelle de l'Afrique du Nord, 9, 153-156.

Santschi, F. (1921a) Notes sur les fourmis paléarctiques. II. Fourmis d’Asie Mineure récoltées par M. H. Gadeau de Kerville. Boletín de la Real Sociedad Española de Historia Natural, 21, $110-116$.

Santschi, F. (1921b) Notes sur les fourmis paléarctiques. I. Quelques fourmis du nord de l'Afrique et des Canaries. Memorias de la Real Sociedad Española de Historia Natural, Tomo extraordinario publicado con motivo del $50 .^{\circ}$ aniversario de su fundación, 424-436.

Santschi, F. (1921c) Nouvelles fourmis paléarctiques. $3^{\text {ème }}$. note. Boletín de la Real Sociedad Española de Historia Natural, 21, 165-170.

Santschi, F. (1929) Fourmis du Maroc, d’Algérie et de Tunisie. Bulletin et Annales de la Société Entomologique de Belgique, 69, 138-165.

Santschi, F. (1932) Inventa entomologica itineris Hispanici et Maroccani, quod a. 1926 fecerunt Harald et Håkan Lindberg. IX. Fourmis du Bassin Méditerranéen occidental et du Maroc récoltées par MM. Lindberg. Commentationes Biologicae Societas Scientiarum Fennica, 3(14), 1-13.

Santschi, F. (1937) Liste et descriptions de fourmis du Maroc. Bulletin de la Société des Sciences Naturelles du Maroc, 16[1936], 198-210.

Schlick-Steiner, B.C., Steiner, F.M., Sanetra, M., Heller, G., Stauffer, C., Christian, E. \& Seifert, B. (2005) Queen size dimorphism in the ant Tetramorium moravicum (Hymenoptera, Formicidae): Morphometric, molecular genetic and experimental evidence. Insectes Sociaux, 52, 186-193.

Schlick-Steiner, B.C., Steiner, F.M., Moder, K., Seifert, B., Sanetra, M., Dyreson, E., Stauffer, C. \& Christian, E. (2006) A multidisciplinary approach reveals cryptic diversity in western Palearctic Tetramorium ants. Molecular Phylogenetics and Evolution, 40, 259-273.

Schlick-Steiner, B.C., Steiner, F.M., Sanetra, M., Seifert, B., Christian, E. \& Stauffer, C. (in press b) Lineage-specific evolution of an alternative social strategy in Tetramorium ants. Biological Journal of the Linnean Society

Schulz, A. (1996) Tetramorium rhenanum nov. spec. vom "Mittleren Rheintal" in Deutschland (Hymenoptera: Formicidae). Linzer biologische Beiträge, 28, 391-412.

Schulz, A. \& Sanetra, M. (2002) Notes on the socially parasitic ants of Turkey and the synonymy of Epimyrma (Hymenoptera, Formicidae). Entomofauna, 23, 157-172.

Seifert, B. (1988) A taxonomic revision of the Myrmica species of Europe, Asia Minor, and Caucasia (Hymenoptera, Formicidae). Abhandlungen und Berichte des Naturkundemuseums Görlitz, $62(3), 1-75$.

Seifert, B. (1996) Ameisen beobachten, bestimmen, Naturbuch Verlag, Augsburg, 352 pp.

Seifert, B. (2002) The "type" of Myrmica bessarabica Nassonov 1889 and the identity of Myrmica salina Ruzsky 1905 (Hymenoptera: Formicidae, Myrmicinae). Mitteilungen der Münchner Entomologischen Gesellschaft, 92, 93-100.

Sommer, F. \& Cagniant, H. (1988) Étude des peuplements de fourmis des Albères orientales 
(Pyrénées-Orientales, France). (Seconde partie). Vie et Milieu, 38, 321-329.

Stärcke, A. (1942) Die nog onbeschreven Europeesche miervormen. Tijdschrift voor Entomologie, 85, xxiv-xxix.

Steiner, F.M., Schlick-Steiner, B.C., Nikiforov, A., Kalb, R. \& Mistrik, R. (2002) Cuticular hydrocarbons of Tetramorium ants from central Europe: analysis of GC-MS data with self-organizing maps (SOM) and implications for systematics. Journal of Chemical Ecology, 28, 2569-2584.

Steiner, F.M., Schlick-Steiner, B.C., Sanetra, M., Ljubomirov, T., Antonova, V., Christian, E. \& Stauffer, C. (2005) Towards DNA-aided biogeography: An example from Tetramorium ants (Hymenoptera, Formicidae). Annales Zoologici Fennici, 42, 23-35.

Stitz, H. (1917) Ameisen aus dem westlichen Mittelmeergebiet und von den Kanarischen Inseln. Mitteilungen aus dem Zoologischen Museum in Berlin, 8, 333-353.

Tinaut, A. (1991) Contribución al conocimiento de los formícidos del Parque Nacional de Doñana (Hymenoptera, Formicidae). Boletín de la Asociación Española de Entomologia, 15, 57-63.

Tinaut, A. \& Ruano, F. (1994) Contribución al conocimiento de los formícidos de la Sierra de la Estrella (Portugal) (Hymenoptera: Formicidae). Boletín de la Asociación Española de Entomologia, 18, 97-99.

Way, M.J., Cammell, M.E., Paiva, M.R. \& Collingwood, C.A. (1997) Distribution and dynamics of the Argentine ant Linepithema (Iridomyrmex) humile (Mayr) in relation to vegetation, soil conditions, topography and native competitor ants in Portugal. Insectes Sociaux, 44, 415-433.

Wheeler, W.M. (1926) Ants of the Balearic Islands. Folia Myrmecologica et Termitologica, 1, 1-6. Wheeler, W.M. \& Mann, W.M. (1916) The ants of the Phillips expedition to Palestine during 1914. Bulletin of the Museum of Comparative Zoology, 60, 167-174.

Yarrow, I.H.H. (1967) On the Formicidae of the Azores. Boletim do Museu Municipal do Funchal, $21,24-32$. 